Keywords: Neptunium, Sediment, $p H$, Redox

Retention: Permanent

\title{
Neptunium IV and V Sorption to End-Member Subsurface Sediments of the Savannah River Site
}

Todd J. Miller, ${ }^{(a)}$ Brian A. Powell, ${ }^{(a)}$

Daniel I. Kaplan

November 13, 2009

(a) Department of Environmental Engineering and Earth Sciences

Clemson University, Clemson, SC

Savannah River National Laboratory

Savannah River Nuclear Solutions

Aiken, SC 29808

Prepared for the U.S. Department of Energy under contract number DE-AC09-08SR22470.

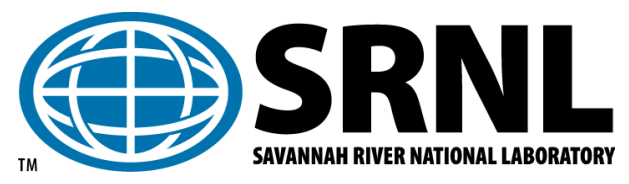


SRNL-STI-2009-00634

Revision 0

\section{DISCLAIMER}

This work was prepared under an agreement with and funded by the U.S. Government. Neither the U.S. Government or its employees, nor any of its contractors, subcontractors or their employees, makes any express or implied:

1. warranty or assumes any legal liability for the accuracy, completeness, or for the use or results of such use of any information, product, or process disclosed; or

2. representation that such use or results of such use would not infringe privately owned rights; or

3. endorsement or recommendation of any specifically identified commercial product, process, or service.

Any views and opinions of authors expressed in this work do not necessarily state or reflect those of the United States Government, or its contractors, or subcontractors.

\section{Printed in the United States of America \\ Prepared for \\ U.S. Department of Energy}




\begin{abstract}
Migration of $\mathrm{Np}$ through the subsurface is expected to be primarily controlled by sorption to sediments. Therefore, understanding and quantifying $\mathrm{Np}$ sorption to sediments and sediments from the Savannah River Site (SRS) is vital to ensure safe disposal of $\mathrm{Np}$ bearing wastes. In this work, $\mathrm{Np}$ sorption to two sediments representing the geological extremes with respect to sorption properties expected in the SRS subsurface environment (named "subsurface sandy sediment" and "subsurface clayey sediment") was examined under a variety of conditions. First a series of baseline sorption tests at $\mathrm{pH} 5.5$ under an oxic atmosphere was performed to understand $\mathrm{Np}$ sorption under typical subsurface conditions. These experiments indicated that the baseline $\mathrm{K}_{\mathrm{d}}$ values for the subsurface sandy and subsurface clayey sediments are $4.26 \pm 0.24 \mathrm{~L} \mathrm{~kg}^{-1}$ and $9.05 \pm 0.61 \mathrm{~L} \mathrm{~kg}^{-1}$, respectively. These $\mathrm{Np} \mathrm{K}_{\mathrm{d}}$ values of SRS sediments are the first to be reported since Sheppard et al. (1979). The previous values were 0.25 and $0.16 \mathrm{~L} \mathrm{~kg}^{-1}$ for a low $\mathrm{pH}$ sandy sediment.

To examine a possible range of $\mathrm{K}_{\mathrm{d}}$ values under various environmental scenarios, the effects of natural organic matter (NOM, also a surrogate for cellulose degradation products), the presence of various chemical reductants, and an anaerobic atmosphere on Np sorption were examined. The presence of NOM resulted in an increase in the $\mathrm{Np} \mathrm{K}_{\mathrm{d}}$ values for both sediments. This behavior is hypothesized to be the result of formation of a ternary Np-NOM-sediment complex. Slight increases in the $\mathrm{Np}$ sorption $\left(\mathrm{K}_{\mathrm{d}} 13-24 \mathrm{~L} \mathrm{~kg}^{-1}\right)$ were observed when performing experiments in the presence of chemical reductants (dithionite, ascorbic acid, zero-valent iron) or under anaerobic conditions. Presumably, the increased sorption can be attributed to a slight reduction of $\mathrm{Np}(\mathrm{V})$ to $\mathrm{Np}(\mathrm{IV})$, the stronger sorbing form of $\mathrm{Np}$. The most significant result of this study is the finding that $\mathrm{Np}$ weakly sorbs to both end member sediments and that $\mathrm{Np}$ only has a slight tendency to reduce to its stronger sorbing form, even under the most strongly reducing conditions expected under natural SRS conditions. Also, it appears that $\mathrm{pH}$ has a profound effect on $\mathrm{Np}$ sorption. Based on the these new measurements and the revelations about $\mathrm{Np}$ redox chemistry, the following changes to "Best $K_{d}$ " values, as defined in Kaplan (2006), for SRS performance assessment calculations are recommended.
\end{abstract}

\begin{tabular}{|l|c|c|}
\hline & $\begin{array}{c}\text { Previous Recommended "Best } \\
\mathrm{K}_{\mathrm{d}}{ }^{\text {"Values }}{ }^{(\mathrm{a})}\left(\mathrm{L} \mathrm{kg}^{-1}\right)\end{array}$ & $\begin{array}{c}\text { New Recommended "Best } \\
\mathrm{K}_{\mathrm{d}} \text { " Values }\left(\mathrm{L} \mathrm{kg}^{-1}\right)\end{array}$ \\
\hline Sandy Sediment & 0.6 & 3 \\
\hline Clay Sediment & $35^{(\mathrm{b})}$ & 9 \\
\hline${ }^{(\mathrm{a})}$ Kaplan (2006; Geochemical Data Package, WSRC-TR-2006-00004) \\
${ }^{(\mathrm{b})}$ An estimate that was based without experimental data. \\
\hline
\end{tabular}




\section{TABLE of CONTENTS}

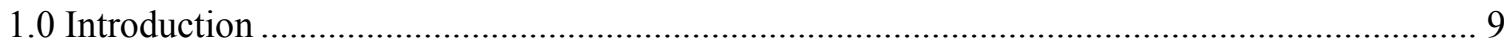

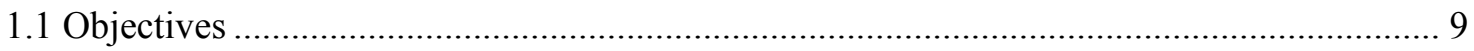

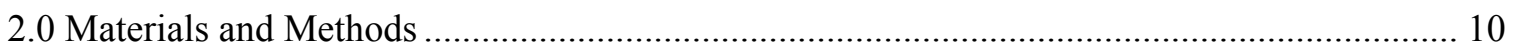

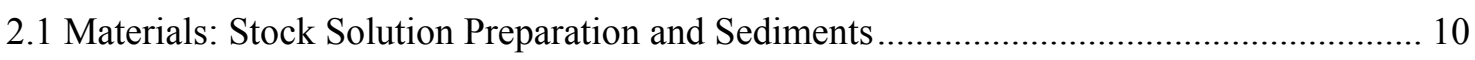

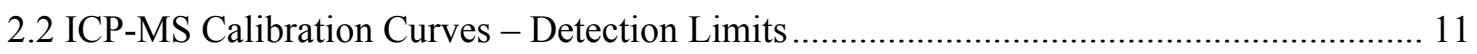

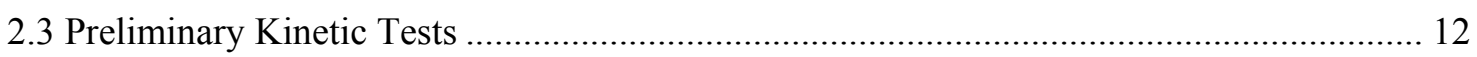

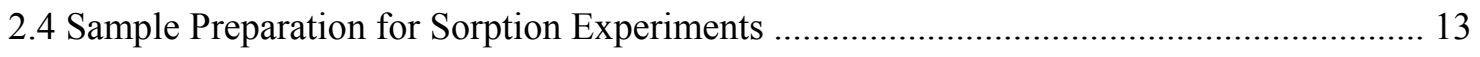

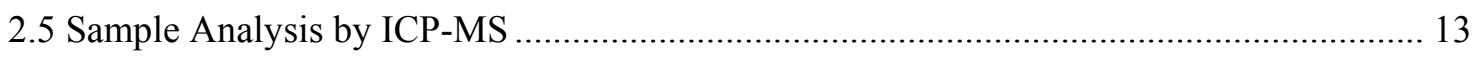

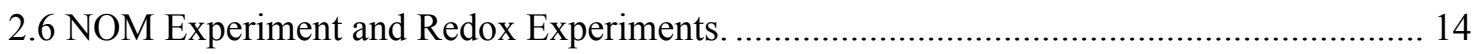

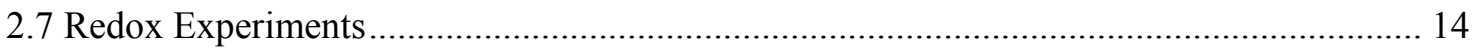

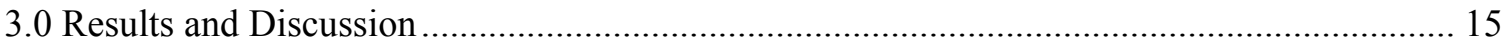

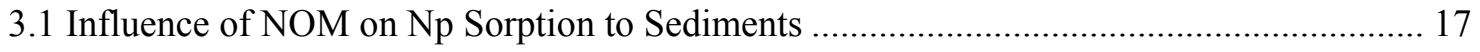

3.2 Influence of Redox Status on Np Sorption to Sediments................................................... 19

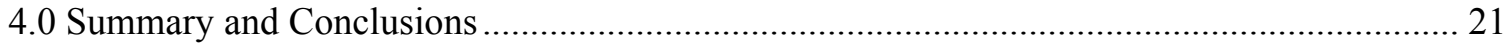

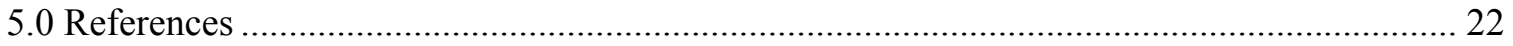

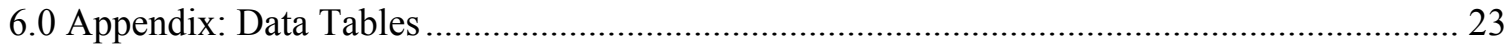

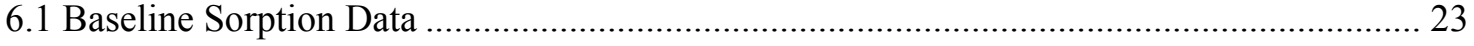

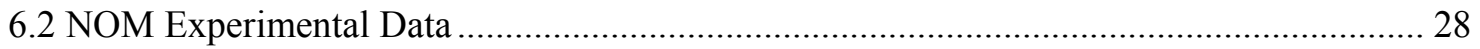

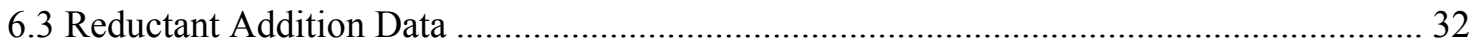

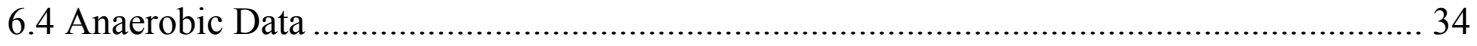




\section{LIST OF FIGURES}

Figure 1.1: Screen capture of a typical ${ }^{237} \mathrm{~Np}$ calibration curve using Thermo PlasmaLab software to control the data collection and analysis. $\mathrm{R}^{2}=0.999993$, Intercept Conc. (Detection Limit) $=$ $0.000018 \mathrm{ppb}$.

Figure 2.1: Clayey Sediment Baseline Sorption Isotherm Data measured after $48 \mathrm{hr}$. [Np] $]_{\mathrm{o}}$ ranged from $0.1 \mathrm{ppb}$ to $50 \mathrm{ppb}$. Sediment concentration of $25 \mathrm{~g} \mathrm{~L}^{-1} \cdot \mathrm{pH}=5.50 \pm 0.01$. Measured $\mathrm{K}_{\mathrm{d}}$ values of $9.05 \pm 0.61 \mathrm{~L} \mathrm{~kg}^{-1}$ and $9.99 \pm 0.28 \mathrm{~L} \mathrm{~kg}^{-1}$ for the centrifuged and filtered samples, respectively. Error determined using linear regression analysis of data to determine $\mathrm{K}_{\mathrm{d}}$ values.

Figure 2.2: Sandy Sediment Baseline Sorption Isotherm. Data measured after 48 hours. $[\mathrm{Np}]_{\mathrm{o}}$ ranged from $0.1 \mathrm{ppb}$ to $50 \mathrm{ppb}$. Sediment concentration of $25 \mathrm{~g} \mathrm{~L}^{-1} \cdot \mathrm{pH}=5.50 \pm 0.03$. Measured $\mathrm{K}_{\mathrm{d}}$ values of $4.26 \pm 0.24 \mathrm{~L} \mathrm{~kg}^{-1}$ and $5.32 \pm 0.16 \mathrm{~L} \mathrm{~kg}^{-1}$ for the centrifuged and filtered samples, respectively. Error determined using linear regression analysis of data to determine $\mathrm{K}_{d}$ values.

Figure 2.3: Effects of NOM on Np Sorption Isotherm Data measured after 48 hours. [Np]o ranged from $0.1 \mathrm{ppb}$ to $20 \mathrm{ppb}$. [NOM]o $=10 \mathrm{mg} \mathrm{L}^{-1}$. Sediment concentration of $25 \mathrm{~g} \mathrm{~L}^{-1}$. $\mathrm{pH}=$ $5.02 \pm 0.22$ for clayey sediment and $\mathrm{pH}=5.71 \pm 0.18$ for Sandy Sediment. International Humic Society Suwannee River NOM was added to the samples at a concentration of $10 \mathrm{mg} \mathrm{L}^{-1}$ and were sampled after an equilibration period of 48 hours. 17

Figure 2.4: Effects of Varying NOM concentrations on Np Sorption Isotherm Data measured after 48 hours. $[\mathrm{Np}]_{\mathrm{o}}=10 \mathrm{ppb}$. $[\mathrm{NOM}]_{\mathrm{o}}$ ranged from $0-20 \mathrm{mg} \mathrm{L}^{-1}$. Sediment concentration of 25 $\mathrm{g} \mathrm{L}^{-1} \cdot \mathrm{pH}=5.55 \pm 0.10$ for Clayey sediment and $\mathrm{pH}=5.51 \pm 0.06$ for Sandy sediment. 18

Figure 2.5: Anaerobic Conditions Data measured after 48 hours. $[\mathrm{Np}]_{\mathrm{o}}$ ranged from $0.1 \mathrm{ppb}$ to $10 \mathrm{ppb}$ for Clayey sediment and $0.1 \mathrm{ppb}$ to $10 \mathrm{ppb}$ for Sandy sediment. Sediment concentration of $25 \mathrm{~g} \mathrm{~L}^{-1} \cdot \mathrm{pH}=5.51 \pm 0.06$ for Clayey sediment and $\mathrm{pH}=5.50 \pm 0.07$ for Sandy sediment. Measured $\mathrm{K}_{\mathrm{d}}$ values of $12.78 \pm 0.10 \mathrm{~L} \mathrm{~kg}^{-1}$ and $12.51 \pm 0.26 \mathrm{~L} \mathrm{~kg}^{-1}$ for the Clayey sediment centrifuged and filtered samples, respectively. Measured $\mathrm{K}_{\mathrm{d}}$ values of $4.55 \pm 0.35 \mathrm{~L} \mathrm{~kg}^{-1}$ and $4.84 \pm 0.38 \mathrm{~L} \mathrm{~kg}^{-1}$ for the Sandy sediment centrifuged and filtered samples, respectively 


\section{LIST OF TABLES}

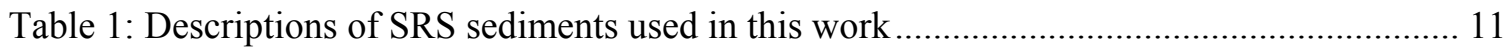

Table 1.2: Example ICP-MS Calibration Curve Data ............................................................... 12

Table 2.1: $\mathrm{K}_{\mathrm{d}}$ Values for $\mathrm{Np}$ Sorption under Reducing Conditions ............................................ 19

Table 5.1:Clayey Centrifugal Data from Baseline Sorption...................................................... 23

Table 5.2: Clayey Filtrate Data from Baseline Sorption ........................................................... 24

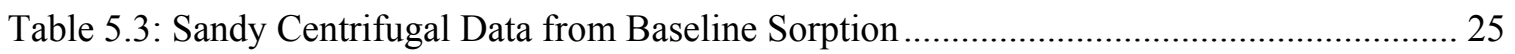

Table 5.4: Sandy Filtrate Data from Baseline Sorption............................................................... 26

Table 5.5: Blank Sample Data from Baseline Sorption............................................................... 27

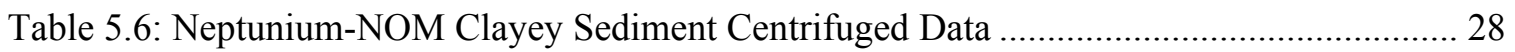

Table 5.7: Neptunium-NOM Clayey Sediment Filtrate Data ..................................................... 28

Table 5.8: Neptunium-NOM Sandy Sediment Centrifuged Data................................................ 29

Table 5.9: Neptunium-NOM Sandy Sediment Filtrate Data …................................................... 29

Table 5.10: Neptunium-Varying NOM Clayey Sediment Centrifuged Data ................................ 30

Table 5.11: Neptunium-Varying NOM Clayey Sediment Filtrate Data ....................................... 30

Table 5.12: Neptunium-Varying NOM Sandy Sediment Centrifuged Data................................. 30

Table 5.13: Neptunium-Varying NOM Sandy Sediment Filtrate Data ........................................ 31

Table 5.14: Reductant Addition Clayey Sediment Centrifuged Data........................................... 32

Table 5.15: Reductant Addition Clayey Sediment Filtrate Data ................................................. 32

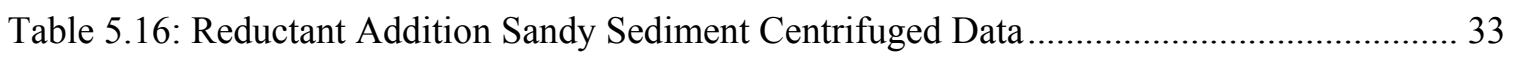

Table 5.17: Reductant Addition Sandy Sediment Filtrate Data ................................................. 33

Table 5.18: Anaerobic Glovebox Clayey Sediment Centrifuged Data......................................... 34

Table 5.19: Anaerobic Glovebox Clayey Sediment Filtrate Data ................................................ 34

Table 5.20: Anaerobic Glovebox Sandy Sediment Centrifuged Data .......................................... 35

Table 5.21: Anaerobic Glovebox Sandy Sediment Filtrate Data ................................................ 36 


\section{LIST OF ABBREVIATIONS}

$\begin{array}{ll}{[\mathrm{Np}]} & \text { Neptunium concentrations } \\ {[\mathrm{Np}]_{\mathrm{o}}} & \text { initial Neptunium concentrations } \\ \text { DDI water } & \text { Distilled deionized water } \\ \mathrm{K}_{\mathrm{d}} & \text { Distribution Coefficient } \\ \mathrm{NOM} & \text { Natural Organic Matter } \\ \mathrm{ppb} & \text { parts per billion } \\ \mathrm{ppq} & \text { parts per quadrillion } \\ \text { QA/QC } & \text { Quality Assurance/Quality Control } \\ \text { SRNL } & \text { Savannah River National Laboratory } \\ \text { SRS } & \text { Savannah River Site }\end{array}$




\section{Neptunium IV and V Sorption to End-Member Subsurface Sediments of the Savannah River Site}

\subsection{Introduction}

In several scenarios at the SRS's E-Area Low-Level Waste Facility, Np has become a key risk driver because of its perceived high mobility, long-half life, and high inventory (WSRC 2008). Neptunium generally exists in surface aquifers as the oxycation $\mathrm{NpO}_{2}^{+}$. This cation sorbs quite weakly to sediments. For example, the last measurement of Np $\mathrm{K}_{\mathrm{d}}$ values using Savannah River Site sediments was only 0.25 and $0.16 \mathrm{~L} \mathrm{~kg}^{-1}$ for a sandy sediment (Sheppard et al. 1979). This value is an especially low $\mathrm{K}_{\mathrm{d}}$ value when compared to other transuranic elements, such as $\mathrm{U}$ or $\mathrm{Pu}$, which have values of about 200 and 290, respectively for sandy SRS sediment (Kaplan 2009). There has been very little laboratory or field research conducted with $\mathrm{Np}$ to understand how it interacts with SRS sediments. Little is known about its tendency to change from its $\mathrm{Np}(\mathrm{V})$ form as $\mathrm{NpO}_{2}{ }^{+}$, to its less mobile form, $\mathrm{Np}(\mathrm{IV})$. By chemical analogy, $\mathrm{Pu}$, which also exists primarily in the +5 oxidation state in the aqueous phase, $\mathrm{PuO}_{2}{ }^{+}$, and which has only one atomic number more than $\mathrm{Np}(\mathrm{Pu}=94)$, readily reduces to $\mathrm{PuO}_{2(s)}$ in a matter of minutes when it comes in contact with vadose zone SRS sediments (Kaplan et al. 2004). Once the $\mathrm{PuO}_{2(s)}$ forms, $\mathrm{Pu}$ solubility decreases sharply to $10^{-9} \mathrm{M}\left(\mathrm{K}_{\mathrm{d}}\right.$ values of $10,000 \mathrm{~L} \mathrm{~kg}^{-1}$; Kaplan et al. 2006). It was this observation that motivated us to expect that some $\mathrm{NpO}_{2}{ }^{+}$might be reduced by SRS sediments.

A second parameter known to have a strong influence on transuranic sorption to sediments is natural organic matter complexation (Artinger et al. 2000). Artinger et al. (2000) reported that when Np complexed with humic substances, it moved faster than the averaged velocity of groundwater in a column experiment. Furthermore, they reported that $\mathrm{Np}(\mathrm{IV})$ complexed stronger than $\mathrm{Np}(\mathrm{V})$ to the humic substances. The E-Area LowLevel Waste Facility contains cellulose degradation products, materials that can degrade to form organic complexes that may behave very similarly to humic acids.

\subsection{Objectives}

The objectives of this study were:

1. to determine if $\mathrm{Np}(\mathrm{V})$ reduces under $\mathrm{SRS}$ environmental conditions to $\mathrm{Np}(\mathrm{IV})$, and if so, quantify the difference in $\mathrm{Np}$ sorption under oxidizing and reducing conditions, and

2. to quantify the influence of the presence of aqueous humic acids on $\mathrm{Np}(\mathrm{V})$ sorption to SRS sediments. 
SRNL-STI-2009-00634

Revision 0

\subsection{Materials and Methods}

\subsection{Materials: Stock Solution Preparation and Sediments}

A composite ${ }^{237} \mathrm{~Np}$ stock solution from the Environmental Engineering and Earth Science, Clemson University inventory (primarily purchased from Isotope Products, Valencia, CA) was evaporated to dryness then the residue was brought up in approximately $5 \mathrm{~mL} 8.0 \mathrm{M}$ $\mathrm{HNO}_{3}$. Then $1.0 \mathrm{M}$ hydroxylamine hydrochloride $\left(\mathrm{NH}_{2} \mathrm{OH}-\mathrm{HCl}\right.$, EMD Chemicals, ACS grade) and water were added to achieve a $3 \mathrm{M} \mathrm{HNO}_{3} / 0.3 \mathrm{M} \mathrm{NH} \mathrm{NH}_{2} \mathrm{OH}-\mathrm{HCl}$ solution. This solution was purified by extraction chromatography using Eichrom TEVA resin packed in a Bio-Rad poly-prep column. The $3 \mathrm{M} \mathrm{HNO}_{3} / 0.3 \mathrm{M} \mathrm{NH}_{2} \mathrm{OH}-\mathrm{HCl} \mathrm{Np}$ solution was loaded on a $2 \mathrm{~mL}$ column and washed with 3 column volumes of $3 \mathrm{M} \mathrm{HNO}_{3}$. The $\mathrm{Np}(\mathrm{IV})$ was eluted with $0.02 \mathrm{M} \mathrm{HCl}+0.2 \mathrm{M}$ $\mathrm{HF}$. The effluent was evaporated to dryness then redissolved in $1.0 \mathrm{M} \mathrm{HNO}_{3}$. Additional $1.0 \mathrm{M}$ $\mathrm{HNO}_{3}$ was added to maintain a approximately $10 \mathrm{~mL}$ then the solution was evaporated to incipient dryness and redissolved in a $5.0 \mathrm{~mL}$ of $1.0 \mathrm{M} \mathrm{HNO}_{3}$. An aliquot of the stock solution was evaporated to dryness on a stainless steel planchet and counted on the EG\&G Ortec Alpha Spectrometer (Octete PC Detectors). No other alpha energies besides ${ }^{237} \mathrm{~Np}$ were observed. The approximate concentration was determined using liquid scintillation counting and little ${ }^{233} \mathrm{~Pa}$ was observed. The fuming in $\mathrm{HNO}_{3}$ as performed at the end of the purification procedure will drive $\mathrm{Np}$ to the soluble pentavalent state. This is the stable oxidation state of $\mathrm{Np}$ under the experimental conditions. Therefore, experiments performed here can be assumed to be initially $\mathrm{Np}(\mathrm{V})$. The exact $\mathrm{Np}$ concentration in this solution was determined using ICP-MS calibrated with a NIST standard as discussed in Section 2.2 below.

Working Solution \#1 was created by pipetting an aliquot of the Np stock solution into a $100 \mathrm{~mL}$ Nalgene Teflon bottle and diluting with 2\% BDH Aristar Ultra $\mathrm{HNO}_{3}$ to give a working solution $\mathrm{Np}$ concentration of approximately $800 \mathrm{ppb}$. Working Solution \#2 was created by pipetting an aliquot of Working Solution $\# 1$ with $2 \% \mathrm{BDH}$ Aristar Ultra $\mathrm{HNO}_{3}$ in a $250 \mathrm{~mL}$ polypropylene bottle to created a target $\mathrm{Np}$ concentration of approximately $50 \mathrm{ppb}$. Analysis on the ICP-MS calibrated against NIST standards as described below gave concentrations of Working Solution \#1 and Working Solution \#2 of $820 \mathrm{ppb}$ and $49.6 \mathrm{ppb}$, respectively. Calibration using the NIST standard is described in Section 3.1.2 below.

The sediments used for these experiments were obtained from the Savannah River Site. The subsurface sandy sediment will be referred to as the sandy sediment and the subsurface clayey sediment will be referred to as the clayey sediment. The clayey sediment was baked in an oven at $85^{\circ} \mathrm{C}$ overnight to remove excess moisture. The sandy sediment did not receive any treatment. Specific characteristics of each sediment are shown in Table 1. 
SRNL-STI-2009-00634

Revision 0

Table 1: Descriptions of SRS sediments used in this work

\begin{tabular}{|c|c|c|c|c|c|}
\hline Name & Description & $\begin{array}{c}\text { Sand/Silt/Clay } \\
(\mathrm{wt} \%)\end{array}$ & $\begin{array}{c}\text { Surface } \\
\text { Area }\left(\mathrm{m}^{2} / \mathrm{g}\right)\end{array}$ & $\mathrm{pH}$ & $\begin{array}{c}\text { Organic } \\
\text { Matter (wt-\%) }\end{array}$ \\
\hline $\begin{array}{c}\text { Subsurface } \\
\text { Sandy }\end{array}$ & $\begin{array}{c}\text { Subsurface Yellow } \\
\text { Sandy Sediment Low } \\
\text { Organic Matter }\end{array}$ & $97 / 2 / 1$ & 1.27 & 5.10 & $<0.01$ \\
\hline $\begin{array}{c}\text { Subsurface } \\
\text { Clayey }\end{array}$ & $\begin{array}{c}\text { Subsurface Red Clayey } \\
\text { Burial Ground Sediment } \\
\text { Low Organic Matter }\end{array}$ & $58 / 30 / 12$ & 15.31 & 4.55 & NA \\
\hline
\end{tabular}

\subsection{ICP-MS Calibration Curves - Detection Limits}

A National Institute of Standards and Technology, Standard Reference Material (NIST SRM 4341) was used to prepare a stock ${ }^{237} \mathrm{~Np}$ solution by dilution in $2 \%$ Aristar Optima $\mathrm{HNO}_{3}$. All volume additions were monitored gravimetrically. This working solution was then used to make a set of $0.01,0.05,1,2,5,10 \mathrm{ppb}$ standards by dilution using $2 \% \mathrm{HNO}_{3}$. Again all volume additions were monitored gravimetrically. These standards were used to calibrate the Thermo Scientific X Series 2 ICP-MS for quantification of ${ }^{237} \mathrm{~Np}$. A representative calibration curve for ${ }^{237} \mathrm{~Np}$ is shown in Figure 2.1. The calibration data from Figure 2.1 are shown in Table 2.2. The instrument performance was monitored using ${ }^{232} \mathrm{Th}$ and ${ }^{238} \mathrm{U}$ as internal standards. The recovery of each sample during analysis was corrected based on the internal standard recovery. The internal standard recoveries remained within standard QA/QC protocols for the instrument (between $80 \%$ and $120 \%$ ).

The calibration curves were used to calculate the measured concentrations of $\mathrm{Np}$ in the samples being analyzed. The typical calibration curve shown in Figure 2.1 gave a minimum detectable limit of $1.8 \mathrm{ppq}$ (parts per quadrillion). This result is consistent with an average minimum detectable quantity of $2 \mathrm{ppq}$ under the configuration of the instrument used for these measurements. 


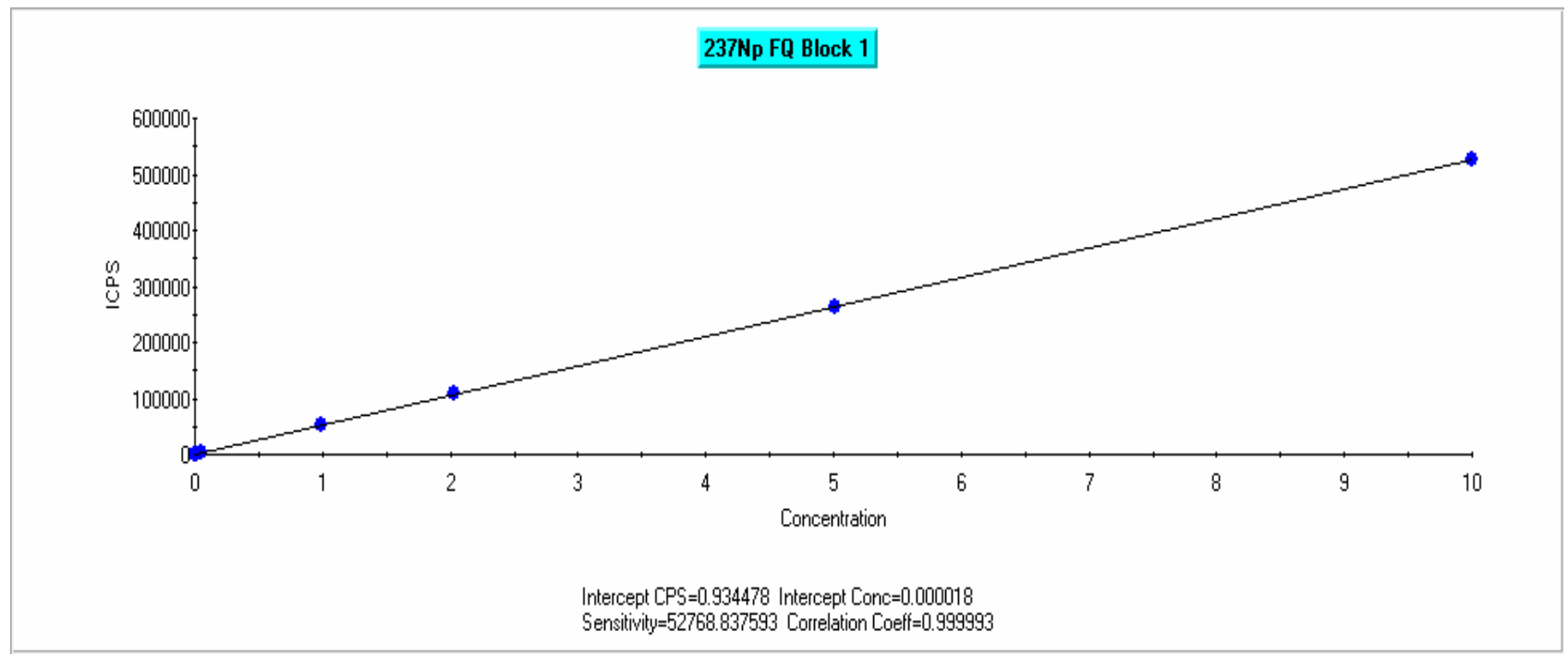

Figure 2.1: Screen capture of a typical ${ }^{237} \mathrm{~Np}$ calibration curve using Thermo PlasmaLab software to control the data collection and analysis. $R^{2}=0.999993$, Intercept Conc. (Detection Limit) $=0.000018$ ppb.

Table 2.2: Example ICP-MS Calibration Curve Data

\begin{tabular}{|c|c|c|c|c|c|}
\hline Sample & $\begin{array}{c}\text { Actual NIST Np } \\
\text { Concentration (ppb) }\end{array}$ & $\begin{array}{c}\text { Measured Np } \\
\text { Concentration (ppb) }\end{array}$ & $\begin{array}{c}\text { Mean Np Ion } \\
\text { Counts Per } \\
\text { Second (ICPS) }\end{array}$ & Error & \% Error \\
\hline \hline Blank & 0 & 0 & 1 & 0 & 0 \\
\hline $0.01 \mathrm{ppb} \mathrm{Np}$ & 0.01 & 0.01 & 528 & 0 & 0.82 \\
\hline $0.05 \mathrm{ppb} \mathrm{Np}$ & 0.05 & 0.05 & 2653 & 0 & 0.53 \\
\hline $1 \mathrm{ppb} \mathrm{Np}$ & 0.991 & 0.993 & 52410 & 0.002 & 0.2 \\
\hline $2 \mathrm{ppb} \mathrm{Np}$ & 2.028 & 2.06 & 108686 & 0.032 & 1.56 \\
\hline $5 \mathrm{ppb} \mathrm{Np}$ & 5.01 & 4.995 & 263575 & -0.015 & -0.3 \\
\hline $10 \mathrm{ppb} \mathrm{Np}$ & 9.998 & 9.999 & 527649 & 0.001 & 0.01 \\
\hline
\end{tabular}

\subsection{Preliminary Kinetic Tests}

Preliminary experiments were performed to determine the time needed to reach steady state sorption between the aqueous $\mathrm{Np}$ and the sorbed $\mathrm{Np}$. This experiment was performed in 45 $\mathrm{mL}$ BD Falcon polypropylene centrifuge tubes. Replicate samples were prepared with sediment concentrations of $5 \mathrm{~g} / \mathrm{L}$ sediment and $25 \mathrm{~g} / \mathrm{L}$ sediment. A fifth tube was used as a control blank. The tubes were first filled with the appropriate mass of sediment, then $4.5 \mathrm{~mL}$ of $0.1 \mathrm{M} \mathrm{NaCl}$ was added, to produce a final constant ionic strength of $0.01 \mathrm{M}$. Next, $40 \mathrm{~mL}$ of distilled deionized water (DDI $\mathrm{H}_{2} \mathrm{O}$ ) was added along with $0.55 \mathrm{~mL}$ of $\mathrm{Np}$ Working Solution \#1 to obtain an initial $\mathrm{Np}$ concentration of $10 \mathrm{ppb}$. The $\mathrm{pH}$ was adjusted to 5.5 using $0.1 \mathrm{~N}$ and $0.01 \mathrm{~N} \mathrm{NaOH}$. The $\mathrm{pH}$ was measured using a VWR $\mathrm{Ag} / \mathrm{AgCl}$ glass electrode calibrated with $\mathrm{pH} \mathrm{4,} \mathrm{7,} \mathrm{and} 10$ buffers (Thermo). The solutions were mixed using an end-over-end rotating tumbler at approximately 8 rpm. 
After $1,3,8,24$, and 48 hours, a $5 \mathrm{~mL}$ aliquot of each suspension was removed. A polyethylene transfer pipette was used to re-suspend any settled sediment particles and remove a homogenous suspension. This sample was then placed in a $15 \mathrm{~mL}$ BD Falcon polypropylene centrifuge tube and centrifuged in a Beckman Coulter Allegra X-22R Centrifuge at $8000 \mathrm{rpm}$ for 20 minutes. This time was sufficient to allow all particles $>100 \mathrm{~nm}$ to settle (Jackson, 1958). A 1 $\mathrm{mL}$ sample of the supernatant was then placed into an ELKay polystyrene culture tube and diluted with $2 \% \mathrm{BDH}$ Aristar Ultra $\mathrm{HNO}_{3}$ for analysis on the ICP-MS. Then $2 \mathrm{~mL}$ of the supernatant was placed into a Microsep $10 \mathrm{~K}$ Centrifugal filter. The samples were then centrifuged in a Beckman GS-6 centrifuge at $3000 \mathrm{rpm}$ for 2-3 minutes to wet the filter membrane and equilibrate $\mathrm{Np}$ with the membrane then the filtrate was discarded. This pre-filtration step equilibrates the solution with the filter and washes the filter preservation coatings away. This treatment results in a significant reduction in the loss of $\mathrm{Np}$ to the filter in the subsequent filtration. The sample was then centrifuged for an additional 20 minutes, or until the entire sample passed through the filter. The filtrate was then transferred into an ELKay polystyrene culture tube and diluted with $2 \% \mathrm{BDH}$ Aristar Ultra $\mathrm{HNO}_{3}$ to determine the Np concentration using the ICPMS.

\subsection{Sample Preparation for Sorption Experiments}

The samples were prepared in $15 \mathrm{~mL}$ BD Falcon polypropylene centrifuge tubes. Each tube was first filled with the appropriate mass of sediment, filled with approximately $6 \mathrm{~mL}$ of DDI- $\mathrm{H}_{2} \mathrm{O}$ and $1 \mathrm{~mL}$ of $0.1 \mathrm{M} \mathrm{NaCl}$ and the $\mathrm{pH}$ was adjusted to an approximate value of 5.5 with $0.1 \mathrm{~N}$ and $0.01 \mathrm{~N} \mathrm{NaOH}$ and $\mathrm{HCl}$. All additions were monitored gravimetrically. The sediment suspension was then mixed end-over-end at approximately $8 \mathrm{rpm}$ for 24 hours to equilibrate with the solution. The samples were then spiked with the Np Working Solution \#1 (described in Section 2.1) to reach target initial concentrations ranging from $0.1 \mathrm{ppb}$ to $50 \mathrm{ppb}$. Finally, water was added to reach a $10 \mathrm{~mL}$ sample volume and the $\mathrm{pH}$ was again adjusted to a $\mathrm{pH}$ of 5.5. The mass of each addition of liquid and sediment to the sample tubes was monitored gravimetrically on Sartorius LA230S analytical balance.

\subsection{Sample Analysis by ICP-MS}

After the 48 hour equilibration period the $\mathrm{pH}$ of each suspension was measured using a VWR Ag/ $\mathrm{AgCl}$ glass electrode. Then a homogenous suspension was obtained by using a VWR 7 $\mathrm{mL}$ polyethylene transfer pipette to suspend the sediment particles. Approximately $1.5 \mathrm{~mL}$ from each suspension was transferred into a $2 \mathrm{~mL}$ polypropylene centrifuge tube and approximately 2 $\mathrm{mL}$ from each suspension was transferred into a Microsep $10 \mathrm{~K}$ Centrifugal filter. The $2 \mathrm{~mL}$ centrifuge tubes were spun at $5000 \mathrm{rpm}$ for 25 minutes in the VWR Galaxy 5D centrifuge to settle particles greater than $100 \mathrm{~nm}$. An Eppendorf research grade pipette was used to draw off the supernatant, typically $1 \mathrm{~mL}$, and transfer it into an ELKay polystyrene culture tube. The mass of the transferred liquid was monitored gravimetrically. The sample was then diluted with $4 \mathrm{~mL}$ of $2 \% \mathrm{BDH}$ Aristar Ultra $\mathrm{HNO}_{3}$ for ICP-MS analysis. Then the suspension in the Microsep 10K centrifugal filter was centrifuged in a Beckman GS-6 centrifuge at $3000 \mathrm{rpm}$ for 2-3 min to wet the filter membrane and equilibrate $\mathrm{Np}$ with the membrane then the filtrate was discarded. The remaining suspension was centrifuged for an additional 20 minutes and the effluent from the $10 \mathrm{~K}$ centrifugal filters was transferred into an ELKay polystyrene culture tube and diluted with $2 \%$ BDH Aristar Ultra $\mathrm{HNO}_{3}$ for ICP-MS analysis. The Np concentration in all samples was determined on the Thermo Scientific X Series 2 ICP-MS. 
The sediment concentration of $\mathrm{Np}$ was calculated using the following equation:

$$
[N p]_{s e d}=\frac{\left([N p]_{a q u, o}-[N p]_{a q u}\right) V_{L}}{m_{\text {sed }}}
$$

Where: $\quad[N p]_{a q u, o}$ : Initial aqueous $\mathrm{Np}$ concentration, $\mathrm{ppb}$

$[N p]_{a q u}$ : Equilibrated (ICP-MS measured) aqueous Np concentration, ppb

$[\mathrm{Np}]_{\text {sed }}$ : Equiibrated sediment $\mathrm{Np}$ concentration, $\mathrm{ppb}$

$V_{L}$ : Sample liquid volume, $\mathrm{mL}$

$m_{\text {sed }}$ : Sample sediment mass, $\mathrm{g}$

The sediment water partitioning constant, $\mathrm{K}_{\mathrm{d}}$, was calculated via the following equation:

$$
K_{d}=\frac{[N p]_{\text {sed }}}{[N p]_{a q u}}
$$

The percent of $\mathrm{Np}$ sorbed can be calculated via the following equation:

$$
f_{s}=1-\frac{[N p]_{a q u}}{[N p]_{a q u, o}}
$$

This $\mathrm{K}_{\mathrm{d}}$ equation (1 and 2) is numerically equivalent to the traditional $\mathrm{K}_{\mathrm{d}}$ equation proposed in ASTM D-4646 which has been used in previous sorption tests (Kaplan et al., 2008).

\subsection{NOM Experiment and Redox Experiments.}

In addition to the baseline experiments described above, this study also aimed to capture the effects of various perturbations to the system to the sorption behavior of $\mathrm{Np}$ on these sediments. The Natural Organic Matter (NOM) used was Suwannee River NOM from the International Humic Substance Society (IHSS). These experiments were performed analogous to the baseline case with the NOM being added before the first equilibration period. The Np spike was then added 24 hours later as in the baseline case. The NOM stock solution was prepared by mixing the dry Suwannee River NOM with DDI water to make a $250 \mathrm{mg} \mathrm{L}^{-1}$ stock solution. A 30 $\mathrm{mg} \mathrm{L}^{-1}$ working solution was also prepared and used to make NOM standards of concentrations $0.1,1.0,2.0,10,20$ and $30 \mathrm{mg} \mathrm{L}^{-1}$. A Cary 50 Bio UV-Visible Spectrometer was used to measure the absorbance at $254 \mathrm{~nm}$ to determine NOM concentrations. This calibration curve was used to determine the NOM concentration in the aqueous phase of centrifuged and filtered samples as described for the $\mathrm{Np}$ analyses above. This information was used to calculate the fraction of NOM sorbed to each sediment using similar equations as 1 and 3, except instead of solving for $\mathrm{Np}$, we solved for NOM.

\subsection{Redox Experiments}

A series of experiments was also performed under reducing conditions or in the presence of chemical reductants in an effort to reduce the weakly sorbing $\mathrm{Np}(\mathrm{V})$ to the more strongly sorbing $\mathrm{Np}(\mathrm{IV})$. The reducing conditions used consisted of the addition of reductants such as ascorbic acid, dithionite, zero-valent iron, and hydrogen peroxide $\left(\mathrm{H}_{2} \mathrm{O}_{2}\right)$. Stock solutions of each 
reductant were prepared at $1000 \mathrm{ppm}$. The stock solutions were added separately to sample vials to obtain a reductant concentration of $10 \mathrm{ppm}$ at the same time the $\mathrm{Np}$ spike was added. The Np concentration in each sample was analyzed as stated above. The preliminary experiment was also performed in an anaerobic glovebox with an atmosphere of $98 \% \mathrm{~N}_{2}$ and $2 \% \mathrm{H}_{2}$. All water used for the experiment was deoxygenated by boiling for 30 min then cooling under a nitrogen gas purge. The Np stock solutions were deoxygenated by uncapping the bottles and stirring the solution for $24 \mathrm{~h}$ within the glovebox. The samples were analyzed as described in Section 2.5 above.

\subsection{Results and Discussion}

For the baseline case, the samples were prepared then sampled after 48 hours. The $\mathrm{K}_{\mathrm{d}}$ values for the clayey sediment were calculated to be $9.05 \pm 0.61 \mathrm{~L} \mathrm{~kg}^{-1}$ and $9.99 \pm 0.28 \mathrm{~L} \mathrm{~kg}^{-1}$ for the centrifuged and filtrate samples, respectively (Figure 3.1). The slightly larger filter $\mathrm{K}_{\mathrm{d}}$ value is the result of filtering out $>100 \mathrm{~nm}$ colloid particles holding $\mathrm{Np}$, that were measured originally in the aqueous phase, thereby producing a lower $K_{d}$ (because $K_{d}=N p_{\text {sed }} / N_{p q}$ ). $K_{d}$ values for the sandy sediment were calculated to be $4.26 \pm 0.24 \mathrm{~L} \mathrm{~kg}^{-1}$ and $5.32 \pm 0.16 \mathrm{~L} \mathrm{~kg}^{-1}$ for the centrifuged and filtrate samples, respectively (Figure 3.3). The data shows a stronger interaction of the Np with the clayey sediment than the sandy sediment. The stronger interaction of $\mathrm{Np}$ with the clayey sediment was likely due to the higher surface area of the clayey sediment and the relatively poor interactions of $\mathrm{Np}$ with silica surfaces which may dominate the sandy sediment (Righetto et al., 1991; Bertetti et al., 1998). The data also show that there is an increase in $\mathrm{K}_{\mathrm{d}}$ with the filtration step. This behavior indicates that a small fraction of $\mathrm{Np}$ may be associated with colloidal particles in the $4-100 \mathrm{~nm}$ size range.

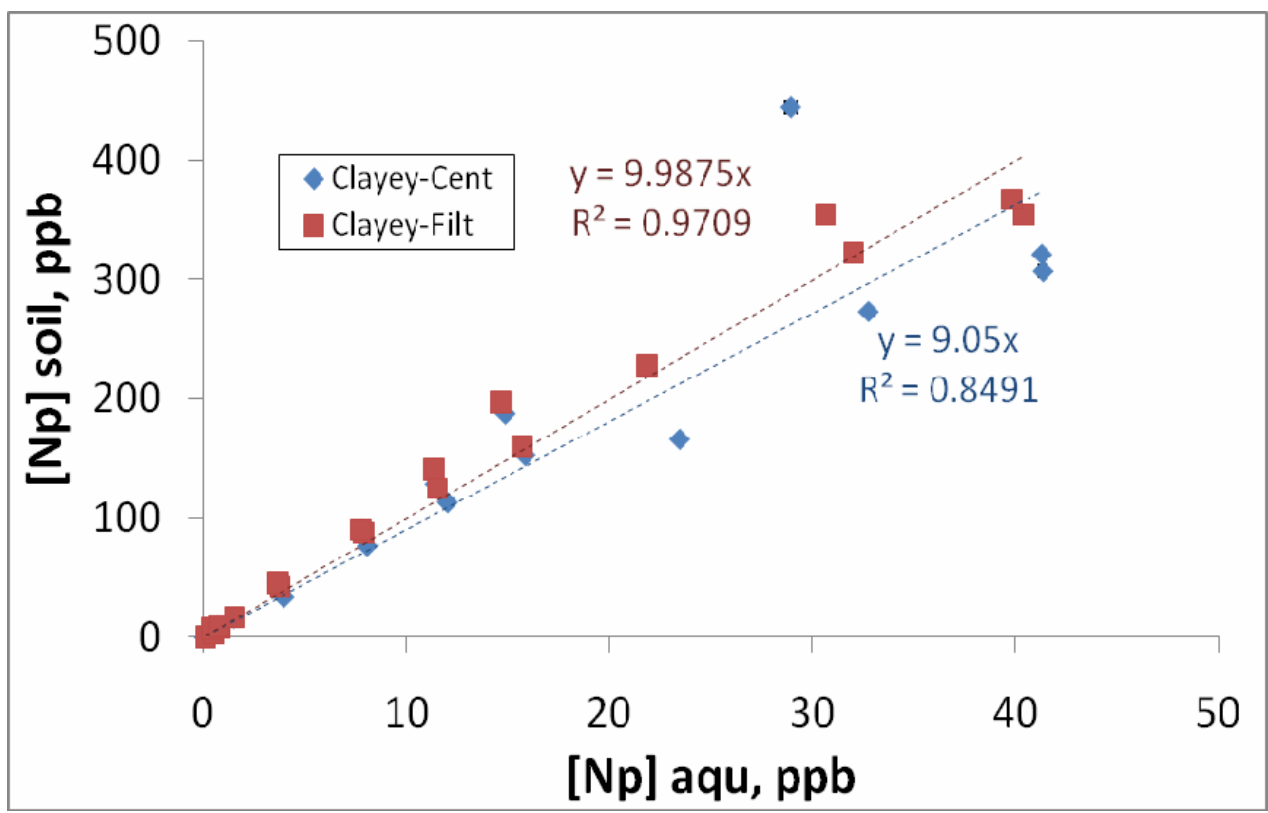

Figure 3.1: Clayey Sediment Baseline Sorption Isotherm Data measured after $48 \mathrm{hr}$. [Np] ranged from $0.1 \mathrm{ppb}$ to $50 \mathrm{ppb}$. Sediment concentration of $25 \mathrm{~g} \mathrm{~L}^{-1} \cdot \mathrm{pH}=5.50 \pm 0.01$. Measured $K_{d}$ values of $9.05 \pm 0.61 \mathrm{~L} \mathrm{~kg}^{-1}$ and $9.99 \pm 0.28 \mathrm{~L} \mathrm{~kg}^{-1}$ for the centrifuged and filtered samples, respectively. Error determined using linear regression analysis of data to determine $K_{d}$ values. 


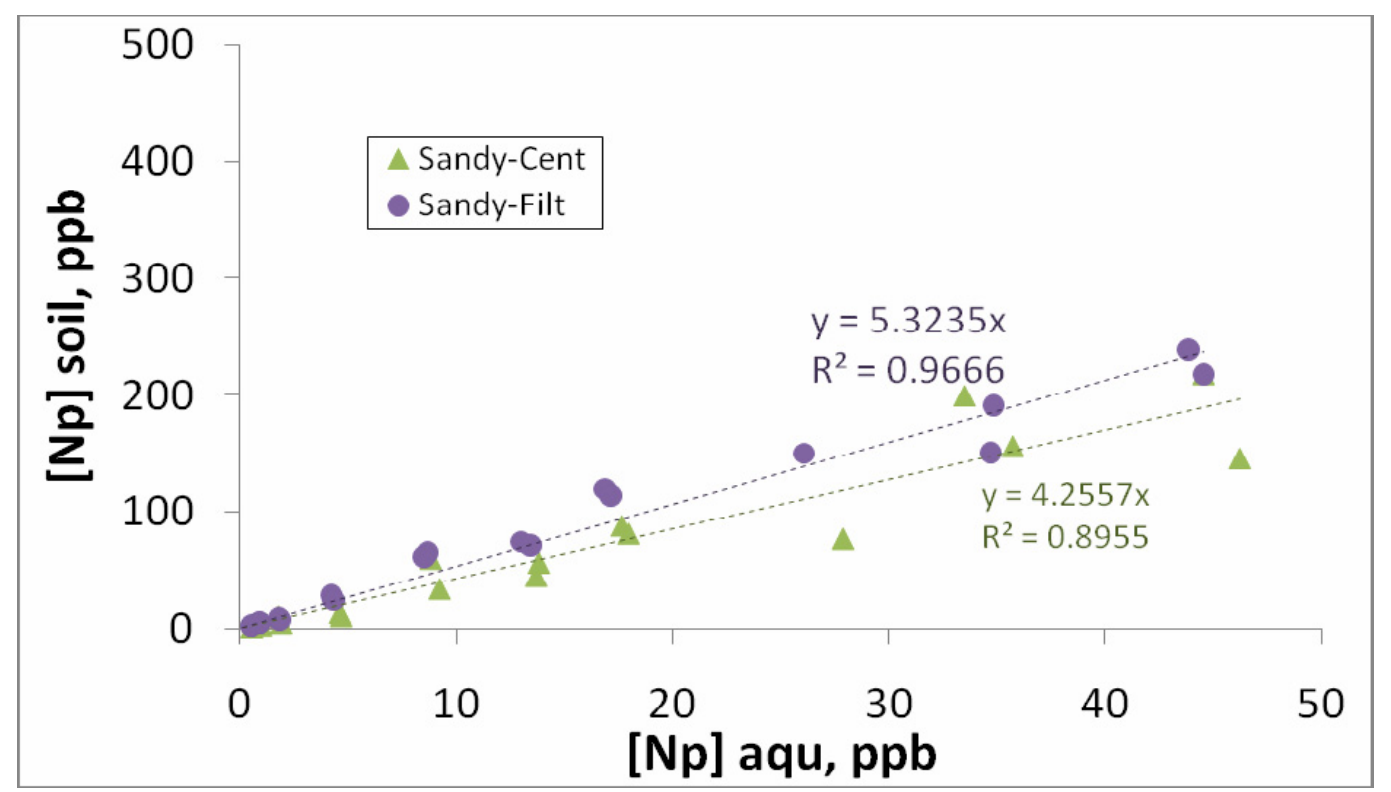

Figure 3.2: Sandy Sediment Baseline Sorption Isotherm. Data measured after 48 hours. $[\mathrm{Np}]_{o}$ ranged from $0.1 \mathrm{ppb}$ to $50 \mathrm{ppb}$. Sediment concentration of $25 \mathrm{~g} \mathrm{~L}^{-1} \cdot \mathrm{pH}=5.50 \pm 0.03$. Measured $K_{d}$ values of $4.26 \pm 0.24 \mathrm{~L} \mathrm{~kg}^{-1}$ and $5.32 \pm 0.16 \mathrm{~L} \mathrm{~kg}^{-1}$ for the centrifuged and filtered samples, respectively. Error determined using linear regression analysis of data to determine $K_{d}$ values.

It has been shown that the sorption of $\mathrm{Np}$ onto amorphous silica and $\gamma$-alumina at low $\mathrm{pH}$ increases with increasing humic acid concentration (Righetto, et al. 1991). This behavior is attributed to the sediments becoming coated with the humic acids causing the surface charge to become more negative thus more strongly attracting the cationic $\mathrm{NpO}_{2}{ }^{+}$, thus forming a ternary metal-ligand-surface complex. There was evidence of this effect in the final NOM concentration. For most of the samples, the NOM concentration decreased from the initial concentration of 10 $\mathrm{mg} \mathrm{L}^{-1}$ indicating sorption of NOM to the sediment surface. There was also increased sorption of $\mathrm{Np}$ to the sediments.

At low initial $\mathrm{Np}$ concentrations, "[Np]," there was little sorption of $\mathrm{Np}$ to the sediment (

Figure 3.3). Overall, the addition of the NOM increased sorption of $\mathrm{Np}$ to the sediment. The effect of NOM addition was seen more with the sandy sediment than the clayey sediment, but his was seen only at the highest NOM concentration. However, $\mathrm{pH}$ control was an issue with these samples, so the higher $\mathrm{pH}$ for the sandy samples (5.7 versus 5.0 for the clayey sediments) could have added to the increase in sorption. Increased sorption with increasing $\mathrm{pH}$ is expected for metal cations and has been frequently observed for $\mathrm{Np}$ sorption to various solids (Righetto, et al. 1991; Girvin, et al. 1990). There was also an increase in $\mathrm{K}_{\mathrm{d}}$ with the filtration step, again, a result of colloidal $\mathrm{Np}$ being removed from what was assumed to be aqueous $\mathrm{Np}\left(\mathrm{K}_{\mathrm{d}}=\right.$ $\mathrm{Np}_{\text {sed }} / \mathrm{Np}_{\mathrm{aq}}$ ). This result indicates that there is small fraction of $\mathrm{Np}$ associated with colloidal particles in the 4-100 nm size range. However, it should be noted that the filtration step used in these experiments will likely remove some fraction of the NOM. The data shown in

Figure 3.3 indicate that the $\mathrm{pH}$ of the suspension has an impact on $\mathrm{Np}$ sorption as observed in previous studies (Righetto, et al. 1991; Girvin, et al. 1990; Bertetti et al., 1998). 


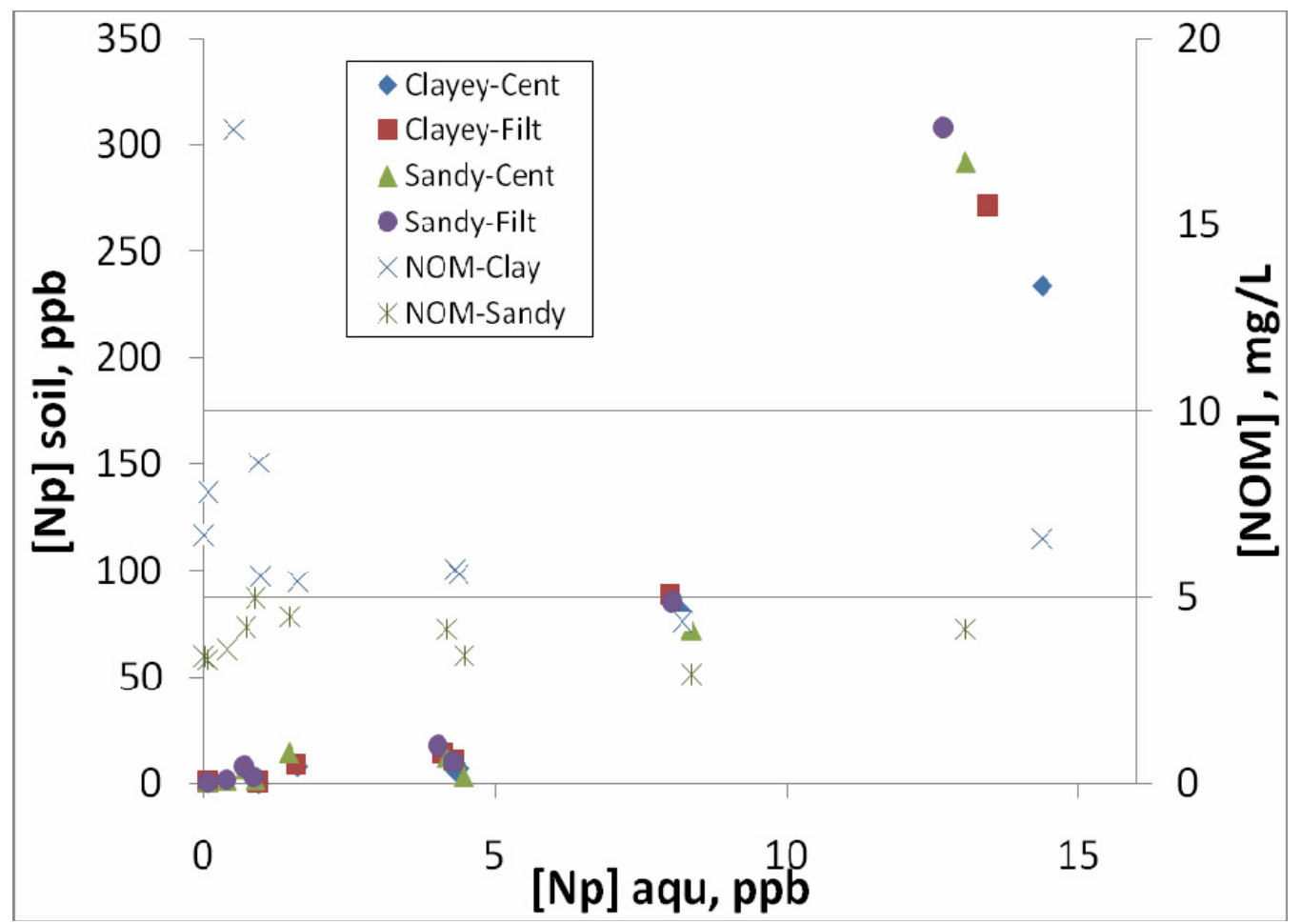

Figure 3.3: Effects of NOM on Np Sorption Isotherm Data measured after 48 hours. [Np]o ranged from $0.1 \mathrm{ppb}$ to $20 \mathrm{ppb}$. [NOM] $=10 \mathrm{mg} \mathrm{L}^{-1}$. Sediment concentration of $25 \mathrm{~g} \mathrm{~L}^{-1}$. pH $=5.02 \pm 0.22$ for clayey sediment and $\mathrm{pH}=\mathbf{5 . 7 1} \pm \mathbf{0 . 1 8}$ for Sandy Sediment. International Humic Society Suwannee River NOM was added to the samples at a concentration of $10 \mathrm{mg}$ $L^{-1}$ and were sampled after an equilibration period of 48 hours.

The sorption isotherm in

Figure 3.3 is, instead of being linear, exponential over this Np concentration range. This behavior indicates that the $\mathrm{K}_{\mathrm{d}}$ construct is not appropriate over this entire range, 0 to $15 \mathrm{ppb}$. It also indicates that more complicating surface chemistry may be occurring. It is important to note that sorption sharply increases, not decreases, at higher Np concentrations. When competitive sorption occurs, then decreased sorption occurs and a plateau sorption occurs at elevated aqueous solute concentrations. However, in this study, the increase is not steep enough to suggest precipitation, but perhaps some early stages of precipitation.

\subsection{Influence of NOM on Np Sorption to Sediments}

To explore the effects of NOM on Np sorption further, an additional experiment was performed in which the concentration of NOM was varied and the initial $\mathrm{Np}$ concentration was held at $10 \mathrm{ppb}$, where $\mathrm{Np}$ sorption was elevated, but had not increased sharply. The resulting $\mathrm{K}_{\mathrm{d}}$ values obtained from this experiment are reported in Figure 3.4. As a point of comparison, the $\mathrm{K}_{\mathrm{d}}$ values for the clayey sediment at $[\mathrm{Np}]_{\mathrm{o}}=10 \mathrm{ppb}$ are $9.75 \pm 1.28 \mathrm{~L} \mathrm{~kg}^{-1}$ and $11.09 \pm 1.35 \mathrm{~L} \mathrm{~kg}^{-1}$ for the centrifuged and filtered samples, respectively. For the sandy sediment, $K_{d}$ values of $8.62 \pm$ $1.38 \mathrm{~L} \mathrm{~kg}^{-1}$ and $10.57 \pm 1.31 \mathrm{~L} \mathrm{~kg}^{-1}$ for the centrifuged and filtered samples, respectively (data from

Figure 3.3 above). 


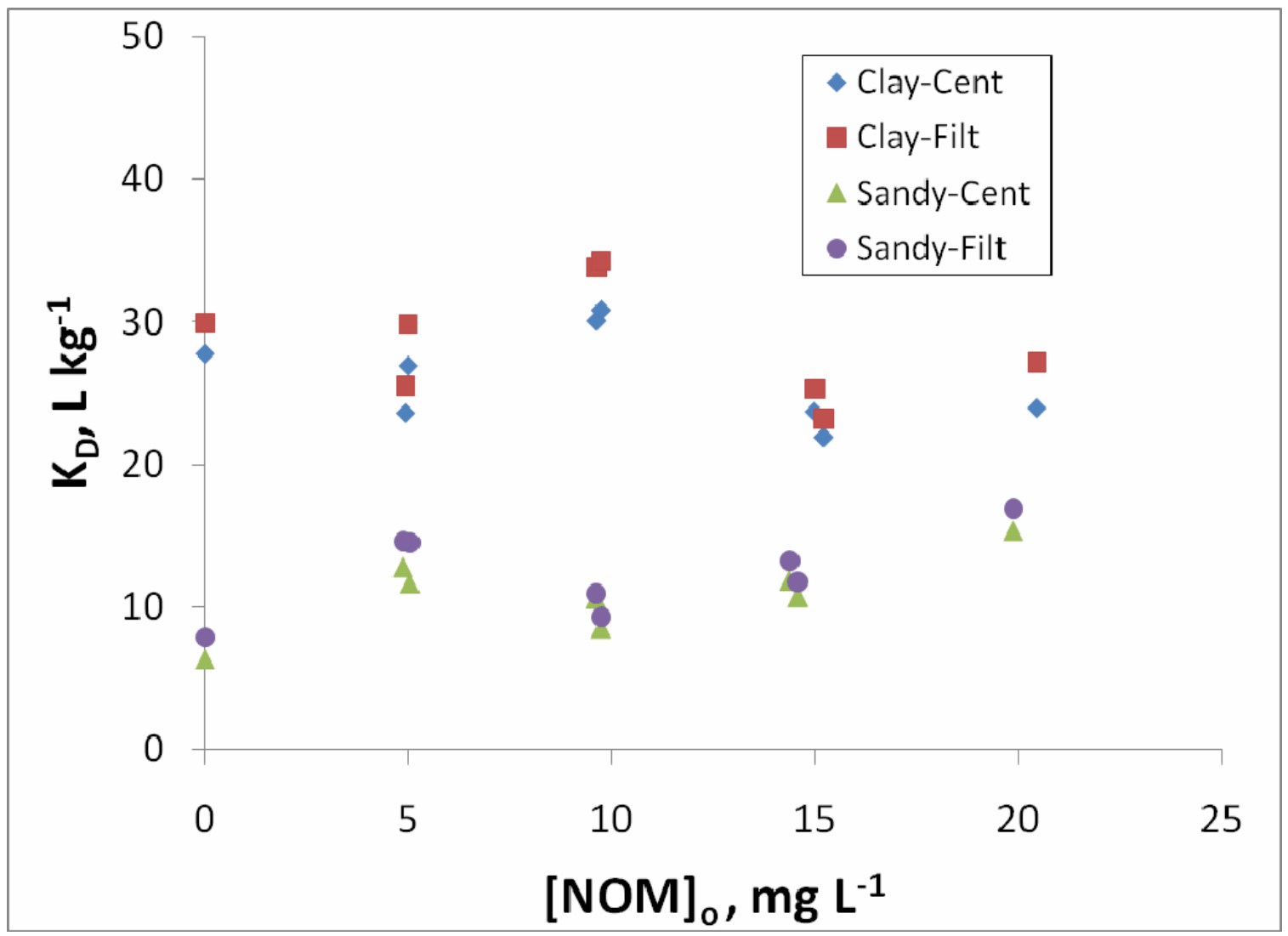

Figure 3.4: Effects of Varying NOM concentrations on Np Sorption Isotherm Data measured after 48 hours. $[\mathrm{Np}]_{0}=10 \mathrm{ppb}$. $[\mathrm{NOM}]_{0}$ ranged from $0-20 \mathrm{mg} \mathrm{L}^{-1}$. Sediment concentration of $25 \mathrm{~g} \mathrm{~L}^{-1} \cdot \mathrm{pH}=\mathbf{5 . 5 5} \pm \mathbf{0 . 1 0}$ for Clayey sediment and $\mathrm{pH}=\mathbf{5 . 5 1} \pm \mathbf{0 . 0 6}$ for Sandy sediment.

The NOM initial concentration, $[\mathrm{NOM}]_{\mathrm{o}}$, was varied from $0-20 \mathrm{mg} \mathrm{L}^{-1}$ and $[\mathrm{Np}]_{\mathrm{o}}$ for all samples was $10 \mathrm{ppb}$. The data show no effect of $[\mathrm{NOM}]$ on $\mathrm{K}_{d}$ values. The $\mathrm{K}_{\mathrm{d}}$ values for the clayey sediment were $25.78 \pm 1.14 \mathrm{~L} \mathrm{~kg}^{-1}$ and $28.19 \pm 1.40 \mathrm{~L} \mathrm{~kg}^{-1}$ for the centrifuged and filtered samples, respectively. For the sandy sediments, the $\mathrm{K}_{\mathrm{d}}$ values were $10.70 \pm 0.98 \mathrm{~L} \mathrm{~kg}^{-1}$ and 12.13 $\pm 1.07 \mathrm{~L} \mathrm{~kg}^{-1}$ for the centrifuged and filtered samples, respectively. The increase for the clayey sediment $\mathrm{K}_{\mathrm{d}}$ from approximately $10 \mathrm{~L} \mathrm{~kg}^{-1}$ is attributed to the increase in $\mathrm{pH}$ between the two experiments. The initial NOM experiment described in Figure 3.4 was performed at pH 5.0 and the experiment described in Figure 3.4 where the NOM concentration was varied was performed at $\mathrm{pH}$ 5.5. This increase in the $\mathrm{pH}$, again in the presence of NOM, resulted in a marked increase in the $\mathrm{K}_{\mathrm{d}}$ value. Again, this demonstrates a profound effect of $\mathrm{pH}$ on these systems that warrants further study.

The $\mathrm{K}_{\mathrm{d}}$ values measured in the presence of NOM were greater than those for the baseline study presented in Figure 3.1 and Figure 3.2. Therefore, the presence of NOM appears to increase sorption of $\mathrm{Np}$. This result is likely due to the formation of ternary surface complexes as described by Schindler et al. (1990).

Schindler et al. (1990) characterized two types of ternary metal (M), ligand (L), surface (SOH) complexes as Type A and Type B ternary surface complexes. Type A complexation involves a metal ligand complex (ML) forming a further complex with the surface. This can be 
shown as $\equiv \mathrm{S}-\mathrm{O}-\mathrm{M}-\mathrm{L}$, or, in this case, $\equiv \mathrm{S}-\mathrm{O}-\mathrm{Np}-\mathrm{NOM}$. Type $\mathrm{B}$ complexation is when the ligand acts as a bridging ligand in the ternary system. This can be shown as $\equiv \mathrm{S}-\mathrm{O}-\mathrm{L}-\mathrm{M}$, or, in this case, $\equiv$ S-O-NOM-Np. Since it was previously theorized that the organic matter coated the surface sites which, in turn, increased sorption, Type B complexation is the likely scenario in these studies which results in increased $\mathrm{Np}$ sorption in the presence of NOM. This conclusion is also consistent with observed sorption of NOM to the solid phases at the $\mathrm{pH}(\sim 5.5)$ of the batch experiments as shown in

Figure 3.3.

\subsection{Influence of Redox Status on Np Sorption to Sediments}

The purpose of the addition of reductants was to investigate the tendency of $\mathrm{Np}(\mathrm{V})$ reduction in sediments to $\mathrm{Np}(\mathrm{IV})$. Actinides follow the sorption affinity trend of:

$$
\mathrm{An}(\mathrm{IV})>\operatorname{An}(\mathrm{VI})>\operatorname{An}(\mathrm{III})<\mathrm{An}(\mathrm{V})
$$

with tetravalent actinides sorbing the strongest and pentavalent actinides sorbing the weakest. If $\mathrm{Np}(\mathrm{V})$ is reduced to $\mathrm{Np}(\mathrm{IV}), \mathrm{Np}$ sorption will increase, thus decreasing its subsurface mobility. Ascorbic acid, dithionide, zero valent iron, and hydrogen peroxide were selected as "environmentally relevant" reductants to examine in the sediment-aqueous- $\mathrm{Np}(\mathrm{V})$ system.

For each sample, the initial $\mathrm{Np}(\mathrm{V})$ concentration was fixed at $10 \mathrm{ppb}$ and the reductant concentration was $10 \mathrm{ppm}$. Compared to the baseline oxic clayey sediment that had a $\mathrm{K}_{\mathrm{d}}$ value of $9.05 \mathrm{~L} \mathrm{~kg}^{-1}$ (Figure 3.1) and the sandy sediment, which had a $\mathrm{K}_{\mathrm{d}}$ of $4.26 \mathrm{~L} \mathrm{~kg}^{-1}$ (Figure 3.2), the amount of reduction induced by the various treatments was relatively small (Table 3.1). The increases in sorption are consistent with the three reductants, ascorbic acid, dithionide, and zerovalent iron reducing a small fraction of $\mathrm{Np}(\mathrm{V})$ to $\mathrm{Np}(\mathrm{IV})$. Higher concentrations of the reductants could have been used and may have resulted in more reduction of $\mathrm{Np}(\mathrm{V})$ to $\mathrm{Np}(\mathrm{IV})$, however, this concentration was used to simulate potential environmental conditions.

Table 3.1: $K_{d}$ Values for Np Sorption under Reducing Conditions

\begin{tabular}{|c|c|c|}
\hline \multirow{2}{*}{ Treatment } & \multicolumn{2}{|c|}{$\mathrm{K}_{\mathrm{d}}$ Values $\left(\mathrm{L} \mathrm{kg}^{-1}\right)$} \\
\hline & Clayey & Sandy \\
\hline Control (No treatment) & $9.05 \pm 0.61^{\text {(a) }}$ & $4.26 \pm 0.24^{(b)}$ \\
\hline Ascorbic Acid & $21.06 \pm 0.74$ & $12.76 \pm 0.46$ \\
\hline Dithionide & $22.96 \pm 0.56$ & $11.14 \pm 0.80$ \\
\hline Zero-valent Iron & $23.65 \pm 0.58$ & $11.99 \pm 0.46$ \\
\hline Hydrogen Peroxide & $12.47 \pm 0.46$ & $9.23 \pm 0.42$ \\
\hline Anaerobic Chamber ${ }^{(\mathrm{c})}$ & $12.78 \pm 0.10$ & $4.55 \pm 0.35$ \\
\hline
\end{tabular}

(a) Data from Figure 3.1 for the centrifuged samples.

(b) Data from Figure 3.2 for the centrifuged samples.

(c) Data from Figure 3.5 for the centrifuged samples 
A ranking of the treatments by their redox status at the $\mathrm{pH}$ of the sediment, $\mathrm{pH} 5.5$, was not measured but is expected to be:

hydrogen peroxide $<$ control $<$ ascorbic acid $<$ dithionite $<$ zero-valent iron.

Based on the $\mathrm{K}_{\mathrm{d}}$ values in Table 3.1, certainly the oxidation did not occur by hydrogen peroxide. The ascorbic acid, dithionide, and zero-valent iron only promoted a small increase in sorption, and potentially only a small reduction in $\mathrm{Np}(\mathrm{V})$ to $\mathrm{Np}(\mathrm{IV})$.

Microbial respiration in subsurface environments may also generate a reducing, anaerobic environment. Therefore, experiments were performed in an anaerobic glovebox with an atmosphere of $98 \% \mathrm{~N}_{2}(\mathrm{~g})$ and $2 \% \mathrm{H}_{2}(\mathrm{~g})$. The $[\mathrm{Np}]_{\text {o }}$ ranged from $0.1-20 \mathrm{ppb}$ with a fixed sediment concentration of $25 \mathrm{~g} \mathrm{~L}^{-1}$. The $\mathrm{K}_{\mathrm{d}}$ values for the clayey sediment were $12.78 \pm 0.10 \mathrm{~L}$ $\mathrm{kg}^{-1}$ and $12.51 \pm 0.26 \mathrm{~L} \mathrm{~kg}^{-1}$ for the centrifuged and filtered samples, respectively. For the sandy sediments, the $\mathrm{K}_{\mathrm{d}}$ values were $4.55 \pm 0.35 \mathrm{~L} \mathrm{~kg}^{-1}$ and $4.84 \pm 0.37 \mathrm{~L} \mathrm{~kg}^{-1}$ for the centrifuged and filtered samples, respectively. There was little change in the $\mathrm{K}_{\mathrm{d}}$ values from the baseline case. This behavior indicates that little or no reduction of $\mathrm{Np}(\mathrm{V})$ to $\mathrm{Np}(\mathrm{IV})$ occurred under anaerobic (reducing) conditions.

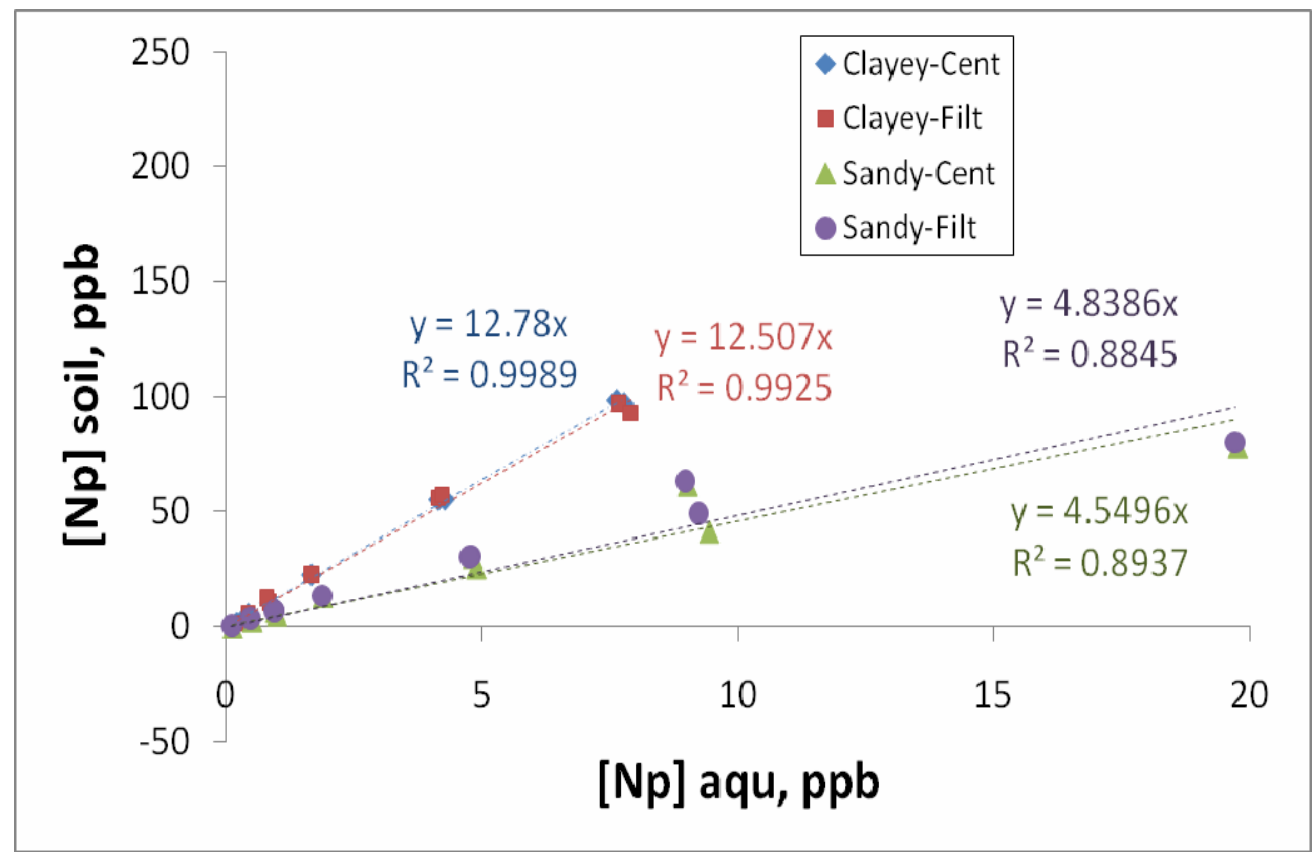

Figure 3.5: Anaerobic Conditions Data measured after 48 hours. [Np] ${ }_{0}$ ranged from 0.1ppb to $10 \mathrm{ppb}$ for Clayey sediment and $0.1 \mathrm{ppb}$ to $10 \mathrm{ppb}$ for Sandy sediment. Sediment concentration of $25 \mathrm{~g} \mathrm{~L}^{-1} \cdot \mathrm{pH}=\mathbf{5 . 5 1} \pm \mathbf{0 . 0 6}$ for Clayey sediment and $\mathrm{pH}=\mathbf{5 . 5 0} \pm \mathbf{0 . 0 7}$ for Sandy sediment. Measured $K_{d}$ values of 12.78 $\pm 0.10 \mathrm{~L} \mathrm{~kg}^{-1}$ and $12.51 \pm 0.26 \mathrm{~L} \mathrm{~kg}^{-1}$ for the Clayey sediment centrifuged and filtered samples, respectively. Measured $K_{d}$ values of $4.55 \pm 0.35 \mathrm{~L}$ $\mathrm{kg}^{-1}$ and $4.84 \pm 0.38 \mathrm{~L} \mathrm{~kg}^{-1}$ for the Sandy sediment centrifuged and filtered samples, respectively. 


\subsection{Summary and Conclusions}

The general conclusions from this work are as follows:

- The baseline $\mathrm{K}_{\mathrm{d}}$ for the clayey sediment was $9.05 \pm 0.61 \mathrm{~L} \mathrm{~kg}^{-1}$

$\circ$ The range of clayey sediment $K_{d}$ values was 9.05 (baseline) to 33.9 (10 ppm $\mathrm{NOM} / 100 \mathrm{~nm}$-filtered) $\mathrm{L} \mathrm{kg}^{-1}$

- The baseline $\mathrm{K}_{\mathrm{d}}$ for the sandy sediment was $4.26 \pm 0.24 \mathrm{~L} \mathrm{~kg}^{-1}$

- The range of sandy sediment $K_{d}$ values for all experiments was 4.26 (baseline) to 16.9 (20 ppm NOM/100nm-filtered) $\mathrm{L} \mathrm{kg}^{-1}$

- There is a stronger interaction (sorption) of the $\mathrm{Np}$ with the clayey sediment than the sandy sediment.

- Due to metals poor interaction with silica which comprises the majority of the sandy sediment

- Greater surface area per mass for clayey sediment $\left(15.07 \mathrm{~m}^{2} / \mathrm{g}\right.$ vs. $\left.1.24 \mathrm{~m}^{2} / \mathrm{g}\right)$

- There was an increase in the $K_{d}$ value with an additional filtration step. This result may indicate that some $\mathrm{Np}$ is associated with 4 to100nm-colloidal material particles

- The additional of Suwannee River NOM resulted in increased Np sorption

- NOM had a greater effect on the $\mathrm{K}_{\mathrm{d}}$ for the sandy sediment as compared with the clayey sediment.

- Varying the NOM concentration did not appear to have a significant effect on $\mathrm{Np}$ sorption.

$\circ$ Changes in the solution $\mathrm{pH}$ between similar experiments in the presence of NOM indicated a profound effect of $\mathrm{pH}$ on the degree of $\mathrm{Np}$ sorption.

- Although minor increases in $\mathrm{K}_{\mathrm{d}}$ values occurred, the addition of reductants or performing the experiments under anaerobic (reducing) conditions did not result in any substantial reduction of $\mathrm{Np}(\mathrm{V})$ to $\mathrm{Np}(\mathrm{IV})$. It is important to note here that reduction (or lack thereof) is inferred from observed sorption behavior, not from direct measurement of the $\mathrm{Np}$ oxidation state using spectroscopic or wet chemistry techniques.

- Based on the these new measurements and the revelations about $\mathrm{Np}$ redox chemistry, the following changes to "Best $\mathrm{K}_{\mathrm{d}}$ " values, as defined in Kaplan (2006), for SRS performance assessment calculations are recommended.

\begin{tabular}{|c|c|c|}
\hline & $\begin{array}{c}\text { Previous Recommended "Best } \\
\mathrm{K}_{\mathrm{d}} \text { "Values }^{(\mathrm{a})}\left(\mathrm{L} \mathrm{kg}^{-1}\right)\end{array}$ & $\begin{array}{c}\text { New Recommended "Best } \\
K_{d} \text { " Values }\left(\mathrm{L} \mathrm{kg}^{-1}\right)\end{array}$ \\
\hline Sandy Sediment & 0.6 & 3 \\
\hline Clay Sediment & $35^{\text {(b) }}$ & 9 \\
\hline
\end{tabular}




\subsection{References}

Artinger, R., C. M. Marquardt, J. I. Kim, A. Seibert, N. Trautmann, and J. V. Kratz. Humic colloid-borne Np migration: Influence of the oxidation state. Radiochim. Acta 88: 609-612.

Bertetti, F.P., R.T. Pabalan, and M.G. Almendarez. 1998. Studies of neptuniumV sorption on quartz, clinoptilolite, montmorillonite, and a-alumina, Chapter 4 in E. Jenne, ed. Adsorption of Metals by Geomedia. San Diego, California: Academic Press. 132-148.

Girvin, D. C., Ames, L. L., Schwab, A. P., McGarrah, J. E., 1991. Neptunium adsorption on synthetic amorphous iron oxyhydroxide. J. Coll. Int. Sci., 141(1), 67-78.

Jackson, M. L., Sediment Chemical Analysis, Prentice Hall, Inc., Englewood Cliffs, NJ., 1958

Kaplan D. I., Roberts, K., Coates, J., Siegfried, M., Serkiz, S. "Saltstone and concrete interactions with radionuclides: sorption $(\mathrm{Kd})$, desorption, and reduction capacity measurements," SRNSSTI-2008-00045, Savannah River Nuclear Solutions, October 2008.

Kaplan, D. I. 2006. Geochemical Data Package for Performance Assessment Calculations Related to the Savannah River Site. WSRC-TR-2006-00004, Rev. 0. Washington Savannah River Company, Aiken, SC.

Kaplan, D. I., B. A. Powell, D. I. Demirkanli, R. A. Fjeld, F. J. Molz, S. M. Serkiz, J. T. Coates. 2004. Enhanced Plutonium Mobility During Long-Term Transport Through an Unsaturated Subsurface Environment. Environ. Sci. Technol. 38:5053-5058.

Kaplan, D. I., D. I. Demirkanli, L. Gumapas, B. A. Powell, R. A. Fjeld, F. J. Molz, and S. M. Serkiz. 2006. 11-Year Field Study of Pu Migration from Pu III, IV, and VI Sources. Environ. Sci. Technol. 40(2): 443-448.

Righetto, L., Bidoglio, G., Azimontl, G. and Bellobono, I.R., 1991. Competitive actinide interactions in colloidal humic acid-mineral oxide systems. Environ. Sci. Technol. 25, 19131919.

Schindler, P.W., in Mineral-Water Interface Geochemistry (M. F. Hochella, Jr., and A. F. White, Eds.), Reviews in Mineralogy, Vol. 23. Mineralogical Society of America, Washington, DC, 1990.

Sheppard, J. C., M. J. Campbell, J. A. Kittrick, and T. L. Hardt. 1979. Retention of Neptunium, Americium, and Curium, by Diffusible Soil Particles. Environ. Sci. Technol. 13:680-684.

WSRC (Washington Savannah River Company LLC) 2008. E-Area Low-Level Waste Facility DOE-435.1 Performance Assessment Volume 1. WSRC-STI-2007-00306, Rev.0. Washington Savannah River Company, Aiken, SC.

WSRC (Washington Savannah River Company LLC) 2008. E-Area Low-Level Waste Facility DOE-435.1 Performance Assessment Volume 1. WSRC-STI-2007-00306, Rev.0. Washington Savannah River Company, Aiken, SC. 


\subsection{Appendix: Data Tables}

Below is the raw data obtained in this work and used to generate the above figures. For the sample descriptions, the first letter denotes the sediment used, $\mathrm{C}$ for clayey and $\mathrm{S}$ for sandy. The following letter indicates whether the sample was the centrifuged (C) sample or the filtered

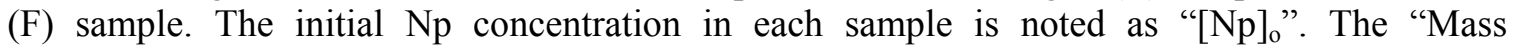
Sediment" column indicates the amount of sediment in each sample. "[Np $]_{\text {aqu" }}$ is the measured aqueous phase concentration of $\mathrm{Np}$ after equilibration. "Mass liquid" gives the total mass of liquid in each sample including any liquid used to adjust the $\mathrm{pH}$. "[Np $]_{\text {sediment" }}$ "was calculated based on the $[\mathrm{Np}]_{\mathrm{o}},[\mathrm{Np}]_{\mathrm{aqu}}$, Mass Liquid and Mass Sediment via equation 1 . The $\mathrm{K}_{\mathrm{d}}$ was calculated using equation 2 . The $\%$ Sorbed was calculated using equation 3 . The $\mathrm{pH}$ values listed below indicate the $\mathrm{pH}$ reading after the equilibration period.

\subsection{Baseline Sorption Data}

Table 6.1:Clayey Centrifugal Data from Baseline Sorption

\begin{tabular}{|c|c|c|c|c|c|c|c|c|}
\hline Sample & {$[\mathrm{Np}]_{\mathrm{o}}$} & $\begin{array}{c}\text { Mass } \\
\left(\mathrm{M}_{\text {sediment }}\right)\end{array}$ & {$[\mathrm{Np}]_{\text {aqu }}$} & $\begin{array}{c}\text { Mass } \\
\text { Liq }\end{array}$ & $\mathrm{Np}]_{\text {sediment }}$ & $\mathrm{K}_{\mathrm{d}}$ & $\%$ Sorbed & $\mathrm{pH}$ \\
\hline Units & $\mathrm{ppb}$ & $\mathrm{g}$ & $\mathrm{ppb}$ & $\mathrm{g}$ & $\mathrm{ppb}$ & $\mathrm{L} \mathrm{kg}^{-1}$ & & \\
\hline \hline $\mathrm{C}-1-\mathrm{C}$ & 0.09 & 0.2550 & 0.09 & 9.86 & 0.17 & 1.92 & $5 \%$ & 5.53 \\
\hline $\mathrm{C}-2-\mathrm{C}$ & 0.56 & 0.2555 & 0.49 & 9.93 & 2.91 & 5.98 & $13 \%$ & 5.50 \\
\hline C-3-C & 0.57 & 0.2432 & 0.43 & 9.92 & 5.72 & 13.17 & $24 \%$ & 5.48 \\
\hline C-4-C & 1.02 & 0.2519 & 0.75 & 9.99 & 10.72 & 14.37 & $27 \%$ & 5.49 \\
\hline C-5-C & 1.01 & 0.2479 & 0.79 & 9.95 & 8.96 & 11.38 & $22 \%$ & 5.51 \\
\hline C-6-C & 1.99 & 0.2415 & 1.58 & 9.98 & 16.88 & 10.70 & $21 \%$ & 5.51 \\
\hline C-7-C & 1.97 & 0.2828 & 1.52 & 9.99 & 16.17 & 10.66 & $23 \%$ & 5.51 \\
\hline C-8-C & 4.90 & 0.2684 & 3.98 & 9.98 & 34.33 & 8.62 & $19 \%$ & 5.51 \\
\hline C-9-C & 4.81 & 0.2523 & 3.66 & 10.11 & 45.92 & 12.54 & $24 \%$ & 5.53 \\
\hline C-10-C & 10.14 & 0.2567 & 7.83 & 10.08 & 90.58 & 11.57 & $23 \%$ & 5.49 \\
\hline C-11-C & 10.02 & 0.2545 & 8.09 & 10.18 & 77.23 & 9.55 & $19 \%$ & 5.49 \\
\hline C-12-C & 14.78 & 0.2425 & 12.04 & 10.03 & 113.14 & 9.39 & $19 \%$ & 5.49 \\
\hline C-13-C & 14.56 & 0.2459 & 11.43 & 10.15 & 129.07 & 11.29 & $21 \%$ & 5.50 \\
\hline C-14-C & 19.74 & 0.2606 & 14.89 & 10.10 & 187.84 & 12.62 & $25 \%$ & 5.49 \\
\hline C-15-C & 19.75 & 0.2544 & 15.87 & 10.02 & 152.89 & 9.64 & $20 \%$ & 5.49 \\
\hline C-16-C & 27.81 & 0.2613 & 23.46 & 10.00 & 166.23 & 7.08 & $16 \%$ & 5.49 \\
\hline C-17-C & 40.30 & 0.2538 & 28.94 & 9.93 & 444.34 & 15.35 & $28 \%$ & 5.50 \\
\hline C-18-C & 39.88 & 0.2591 & 32.76 & 9.94 & 273.28 & 8.34 & $18 \%$ & 5.50 \\
\hline C-19-C & 49.81 & 0.2640 & 41.29 & 9.95 & 321.21 & 7.78 & $17 \%$ & 5.51 \\
\hline C-20-C & 49.10 & 0.2536 & 41.36 & 10.05 & 306.75 & 7.42 & $16 \%$ & 5.52 \\
\hline
\end{tabular}


Table 6.2: Clayey Filtrate Data from Baseline Sorption

\begin{tabular}{|c|c|c|c|c|c|c|c|c|}
\hline Sample & {$[\mathrm{Np}]_{\mathrm{o}}$} & $\begin{array}{c}\text { Mass } \\
\text { Sediment }\end{array}$ & {$[\mathrm{Np}]_{\text {aqu }}$} & Mass Liq & {$[\mathrm{Np}]_{\text {sediment }}$} & $\mathrm{K}_{\mathrm{d}}$ & $\%$ Sorbed & $\mathrm{pH}$ \\
\hline Units & $\mathrm{ppb}$ & $\mathrm{g}$ & $\mathrm{ppb}$ & $\mathrm{g}$ & $\mathrm{ppb}$ & $\mathrm{L} \mathrm{kg}^{-1}$ & & \\
\hline C-1-F & 0.09 & 0.2550 & 0.09 & 9.86 & 0.13 & 1.50 & $4 \%$ & 5.53 \\
\hline $\mathrm{C}-2-\mathrm{F}$ & 0.56 & 0.2555 & 0.47 & 9.93 & 3.61 & 7.69 & $17 \%$ & 5.50 \\
\hline $\mathrm{C}-3-\mathrm{F}$ & 0.57 & 0.2432 & 0.40 & 9.92 & 6.95 & 17.22 & $30 \%$ & 5.48 \\
\hline $\mathrm{C}-4-\mathrm{F}$ & 1.02 & 0.2519 & 0.80 & 9.99 & 8.59 & 10.74 & $21 \%$ & 5.49 \\
\hline $\mathrm{C}-5-\mathrm{F}$ & 1.01 & 0.2479 & 0.77 & 9.95 & 9.80 & 12.79 & $24 \%$ & 5.51 \\
\hline $\mathrm{C}-7-\mathrm{F}$ & 1.99 & 0.2415 & 1.58 & 9.98 & 16.91 & 10.72 & $21 \%$ & 5.51 \\
\hline $\mathrm{C}-8-\mathrm{F}$ & 1.97 & 0.2828 & 1.51 & 9.99 & 16.23 & 10.71 & $23 \%$ & 5.51 \\
\hline $\mathrm{C}-9-\mathrm{F}$ & 4.81 & 0.2523 & 3.67 & 10.11 & 45.57 & 12.41 & $24 \%$ & 5.53 \\
\hline $\mathrm{C}-10-\mathrm{F}$ & 10.14 & 0.2567 & 7.90 & 10.08 & 87.85 & 11.12 & $22 \%$ & 5.49 \\
\hline $\mathrm{C}-11-\mathrm{F}$ & 10.02 & 0.2545 & 7.77 & 10.18 & 89.97 & 11.58 & $22 \%$ & 5.49 \\
\hline $\mathrm{C}-12-\mathrm{F}$ & 14.78 & 0.2425 & 11.38 & 10.03 & 140.69 & 12.37 & $23 \%$ & 5.49 \\
\hline $\mathrm{C}-13-\mathrm{F}$ & 14.56 & 0.2459 & 11.53 & 10.15 & 125.01 & 10.84 & $21 \%$ & 5.50 \\
\hline $\mathrm{C}-14-\mathrm{F}$ & 19.74 & 0.2606 & 14.64 & 10.10 & 197.37 & 13.48 & $26 \%$ & 5.49 \\
\hline $\mathrm{C}-15-\mathrm{F}$ & 19.75 & 0.2544 & 15.69 & 10.02 & 159.98 & 10.20 & $21 \%$ & 5.49 \\
\hline $\mathrm{C}-16-\mathrm{F}$ & 27.81 & 0.2613 & 21.84 & 10.00 & 228.30 & 10.45 & $21 \%$ & 5.49 \\
\hline $\mathrm{C}-17-\mathrm{F}$ & 40.30 & 0.2538 & 32.05 & 9.93 & 322.61 & 10.07 & $20 \%$ & 5.50 \\
\hline $\mathrm{C}-18-\mathrm{F}$ & 39.88 & 0.2591 & 30.65 & 9.94 & 354.19 & 11.56 & $23 \%$ & 5.50 \\
\hline $\mathrm{C}-19-\mathrm{F}$ & 49.81 & 0.2640 & 40.41 & 9.95 & 354.33 & 8.77 & $19 \%$ & 5.51 \\
\hline $\mathrm{C}-20-\mathrm{F}$ & 49.10 & 0.2536 & 39.84 & 10.05 & 367.00 & 9.21 & $19 \%$ & 5.52 \\
\hline
\end{tabular}


Table 6.3: Sandy Centrifugal Data from Baseline Sorption

\begin{tabular}{|c|c|c|c|c|c|c|c|c|}
\hline Sample & {$[\mathrm{Np}]_{\mathrm{o}}$} & $\begin{array}{c}\text { Mass } \\
\text { Sediment }\end{array}$ & {$[\mathrm{Np}]_{\mathrm{aqu}}$} & $\begin{array}{c}\text { Mass } \\
\text { Liq }\end{array}$ & {$[\mathrm{Np}]_{\text {sediment }}$} & $\mathrm{K}_{\mathrm{d}}$ & $\%$ Sorbed & $\mathrm{pH}$ \\
\hline Units & $\mathrm{ppb}$ & $\mathrm{g}$ & $\mathrm{ppb}$ & $\mathrm{g}$ & $\mathrm{ppb}$ & $\mathrm{L} \mathrm{kg}^{-1}$ & & \\
\hline S-1-C & 0.10 & 0.2511 & 0.13 & 9.30 & -1.03 & -8.03 & $-28 \%$ & 5.48 \\
\hline S-2-C & 0.58 & 0.2511 & 0.55 & 9.78 & 1.26 & 2.30 & $6 \%$ & 5.49 \\
\hline S-3-C & 0.58 & 0.2469 & 0.54 & 9.68 & 1.62 & 3.01 & $7 \%$ & 5.50 \\
\hline S-4-C & 1.05 & 0.2608 & 0.93 & 9.73 & 4.41 & 4.74 & $11 \%$ & 5.54 \\
\hline S-5-C & 1.04 & 0.2595 & 0.96 & 9.76 & 2.81 & 2.91 & $7 \%$ & 5.52 \\
\hline S-6-C & 2.04 & 0.2570 & 1.91 & 9.71 & 4.82 & 2.53 & $6 \%$ & 5.49 \\
\hline S-7-C & 2.04 & 0.2447 & 1.78 & 9.67 & 10.37 & 5.84 & $13 \%$ & 5.49 \\
\hline S-8-C & 4.97 & 0.2563 & 4.62 & 9.84 & 13.57 & 2.94 & $7 \%$ & 5.53 \\
\hline S-9-C & 4.94 & 0.2434 & 4.68 & 9.87 & 10.69 & 2.28 & $5 \%$ & 5.48 \\
\hline S-10-C & 10.36 & 0.2477 & 8.83 & 9.67 & 59.84 & 6.78 & $15 \%$ & 5.51 \\
\hline S-11-C & 10.13 & 0.2616 & 9.23 & 9.87 & 33.86 & 3.67 & $9 \%$ & 5.50 \\
\hline S-12-C & 14.78 & 0.2433 & 13.70 & 10.11 & 44.89 & 3.28 & $7 \%$ & 5.55 \\
\hline S-13-C & 15.29 & 0.2556 & 13.82 & 9.80 & 56.48 & 4.09 & $10 \%$ & 5.45 \\
\hline S-14-C & 19.89 & 0.2531 & 17.66 & 9.98 & 87.88 & 4.98 & $11 \%$ & 5.47 \\
\hline S-15-C & 20.04 & 0.2541 & 17.97 & 9.99 & 81.28 & 4.52 & $10 \%$ & 5.45 \\
\hline S-16-C & 29.79 & 0.2475 & 27.88 & 10.01 & 76.85 & 2.76 & $6 \%$ & 5.54 \\
\hline S-17-C & 39.73 & 0.2544 & 35.74 & 9.97 & 156.42 & 4.38 & $10 \%$ & 5.54 \\
\hline S-18-C & 38.48 & 0.2555 & 33.51 & 10.25 & 199.60 & 5.96 & $13 \%$ & 5.47 \\
\hline S-19-C & 49.95 & 0.2510 & 46.23 & 9.86 & 145.88 & 3.16 & $7 \%$ & 5.52 \\
\hline S-20-C & 49.96 & 0.2433 & 44.56 & 9.84 & 218.47 & 4.90 & $11 \%$ & 5.46 \\
\hline
\end{tabular}


Table 6.4: Sandy Filtrate Data from Baseline Sorption

\begin{tabular}{|c|c|c|c|c|c|c|c|c|}
\hline Sample & {$[\mathrm{Np}]_{\mathrm{o}}$} & $\begin{array}{c}\text { Mass } \\
\text { Sediment }\end{array}$ & {$[\mathrm{Np}]_{\text {aqu }}$} & Mass Liq & {$[\mathrm{Np}]_{\text {sediment }}$} & $\mathrm{K}_{\mathrm{d}}$ & $\%$ Sorbed & $\mathrm{pH}$ \\
\hline Units & $\mathrm{ppb}$ & $\mathrm{g}$ & $\mathrm{ppb}$ & $\mathrm{g}$ & $\mathrm{ppb}$ & $\mathrm{L} \mathrm{kg}^{-1}$ & & \\
\hline S-1-F & 0.10 & 0.2511 & 0.12 & 9.30 & -0.70 & -5.82 & $-19 \%$ & 5.48 \\
\hline S-2-F & 0.58 & 0.2511 & 0.50 & 9.78 & 3.14 & 6.27 & $14 \%$ & 5.49 \\
\hline S-3-F & 0.58 & 0.2469 & 0.52 & 9.68 & 2.52 & 4.88 & $11 \%$ & 5.50 \\
\hline S-4-F & 1.05 & 0.2608 & 0.91 & 9.73 & 5.04 & 5.53 & $13 \%$ & 5.54 \\
\hline S-5-F & 1.04 & 0.2595 & 0.89 & 9.76 & 5.46 & 6.12 & $14 \%$ & 5.52 \\
\hline S-6-F & 2.04 & 0.2570 & 1.82 & 9.71 & 8.17 & 4.49 & $11 \%$ & 5.49 \\
\hline S-7-F & 2.04 & 0.2447 & 1.80 & 9.67 & 9.25 & 5.13 & $11 \%$ & 5.49 \\
\hline S-8-F & 4.97 & 0.2563 & 4.23 & 9.84 & 28.39 & 6.71 & $15 \%$ & 5.53 \\
\hline S-9-F & 4.94 & 0.2434 & 4.34 & 9.87 & 24.52 & 5.65 & $12 \%$ & 5.48 \\
\hline S-10-F & 10.36 & 0.2477 & 8.68 & 9.67 & 65.53 & 7.55 & $16 \%$ & 5.51 \\
\hline S-11-F & 10.13 & 0.2616 & 8.50 & 9.87 & 61.27 & 7.21 & $16 \%$ & 5.50 \\
\hline S-12-F & 14.78 & 0.2433 & 12.98 & 10.11 & 74.68 & 5.75 & $12 \%$ & 5.55 \\
\hline S-13-F & 15.29 & 0.2556 & 13.43 & 9.80 & 71.53 & 5.33 & $12 \%$ & 5.45 \\
\hline S-14-F & 19.89 & 0.2531 & 16.85 & 9.98 & 119.57 & 7.10 & $15 \%$ & 5.47 \\
\hline S-15-F & 20.04 & 0.2541 & 17.13 & 9.99 & 114.40 & 6.68 & $15 \%$ & 5.45 \\
\hline S-16-F & 29.79 & 0.2475 & 26.07 & 10.01 & 150.22 & 5.76 & $12 \%$ & 5.54 \\
\hline S-17-F & 39.73 & 0.2544 & 34.84 & 9.97 & 191.45 & 5.49 & $12 \%$ & 5.54 \\
\hline S-18-F & 38.48 & 0.2555 & 34.73 & 10.25 & 150.66 & 4.34 & $10 \%$ & 5.47 \\
\hline S-19-F & 49.95 & 0.2510 & 43.87 & 9.86 & 238.65 & 5.44 & $12 \%$ & 5.52 \\
\hline S-20-F & 49.96 & 0.2433 & 44.57 & 9.84 & 218.20 & 4.90 & $11 \%$ & 5.46 \\
\hline
\end{tabular}


Table 6.5: Blank Sample Data from Baseline Sorption

\begin{tabular}{|c|c|c|c|c|c|}
\hline Sample & {$[\mathrm{Np}] \mathrm{o}$} & {$[\mathrm{Np}]_{\mathrm{aqu}}$} & Mass Liq & $\%$ Sorbed & $\mathrm{pH}$ \\
\hline Units & $\mathrm{ppb}$ & $\mathrm{ppb}$ & $\mathrm{g}$ & & \\
\hline \hline B-10-1-C & 9.42 & 9.13 & 10.79 & $3 \%$ & 5.52 \\
\hline B-10-2-C & 10.62 & 10.48 & 10.13 & $1 \%$ & 5.48 \\
\hline B-50-C & 47.93 & 47.69 & 10.41 & $0 \%$ & 5.50 \\
\hline B-10-1-F & 9.42 & 8.67 & 10.79 & $8 \%$ & 5.52 \\
\hline B-10-2-F & 10.62 & 9.64 & 10.13 & $9 \%$ & 5.48 \\
\hline B-50-F & 47.93 & 45.97 & 10.41 & $4 \%$ & 5.50 \\
\hline
\end{tabular}


6.2 NOM Experimental Data

Table 6.6: Neptunium-NOM Clayey Sediment Centrifuged Data

\begin{tabular}{|c|c|c|c|c|c|c|c|c|}
\hline Sample & {$[\mathrm{Np}]_{\mathrm{o}}$} & $\begin{array}{c}\text { Mass } \\
\text { Sediment }\end{array}$ & {$[\mathrm{Np}]_{\text {aqu }}$} & Liq Mass & {$[\mathrm{Np}]_{\text {sediment }}$} & $\mathrm{K}_{\mathrm{d}}$ & $\%$ Sorbed & $\mathrm{pH}$ \\
\hline Units & $\mathrm{ppb}$ & $\mathrm{g}$ & $\mathrm{ppb}$ & & $\mathrm{ppb}$ & $\mathrm{L} \mathrm{kg}^{-1}$ & & \\
\hline $\mathrm{C}-1-\mathrm{C}$ & 0.09 & 0.24 & 0.08 & 9.92 & 0.41 & 5.00 & $11 \%$ & 5.25 \\
\hline C-2-C & 0.46 & 0.26 & 0.52 & 9.84 & -2.24 & -4.28 & $-13 \%$ & 3.05 \\
\hline C-3-C & 0.95 & 0.26 & 0.98 & 9.90 & -1.14 & -1.17 & $-3 \%$ & 4.56 \\
\hline C-4-C & 0.94 & 0.25 & 0.94 & 9.97 & 0.10 & 0.11 & $0 \%$ & 4.79 \\
\hline C-5-C & 1.82 & 0.26 & 1.61 & 10.12 & 7.95 & 4.93 & $11 \%$ & 5.15 \\
\hline C-6-C & 4.57 & 0.27 & 4.38 & 10.10 & 6.99 & 1.60 & $4 \%$ & 4.98 \\
\hline C-7-C & 4.46 & 0.26 & 4.31 & 10.08 & 5.77 & 1.34 & $3 \%$ & 5.08 \\
\hline C-8-C & 10.29 & 0.26 & 8.21 & 10.17 & 80.04 & 9.75 & $20 \%$ & 5.01 \\
\hline C-9-C & 20.06 & 0.26 & 14.37 & 10.53 & 233.61 & 16.26 & $28 \%$ & 5.26 \\
\hline
\end{tabular}

Table 6.7: Neptunium-NOM Clayey Sediment Filtrate Data

\begin{tabular}{|c|c|c|c|c|c|c|c|c|}
\hline Sample & {$[\mathrm{Np}]_{\mathrm{o}}$} & $\begin{array}{c}\text { Mass } \\
\text { Sediment }\end{array}$ & {$[\mathrm{Np}]_{\text {aqu }}$} & Liq Mass & {$[\mathrm{Np}]_{\text {sediment }}$} & $\mathrm{K}_{\mathrm{d}}$ & $\%$ Sorbed & $\mathrm{pH}$ \\
\hline Units & $\mathrm{ppb}$ & $\mathrm{g}$ & $\mathrm{ppb}$ & & $\mathrm{ppb}$ & $\mathrm{L} \mathrm{kg}^{-1}$ & & \\
\hline $\mathrm{C}-1-\mathrm{F}$ & 0.09 & 0.24 & 0.07 & 9.92 & 0.76 & 10.37 & $20 \%$ & 5.25 \\
\hline $\mathrm{C}-2-\mathrm{F}$ & 0.46 & 0.26 & 0.52 & 9.84 & -2.05 & -3.96 & $-12 \%$ & 3.05 \\
\hline $\mathrm{C}-3-\mathrm{F}$ & 0.95 & 0.26 & 0.95 & 9.90 & -0.27 & -0.29 & $-1 \%$ & 4.56 \\
\hline $\mathrm{C}-4-\mathrm{F}$ & 0.94 & 0.25 & 0.92 & 9.97 & 1.02 & 1.11 & $3 \%$ & 4.79 \\
\hline $\mathrm{C}-5-\mathrm{F}$ & 1.82 & 0.26 & 1.58 & 10.12 & 8.99 & 5.68 & $13 \%$ & 5.15 \\
\hline $\mathrm{C}-6-\mathrm{F}$ & 4.57 & 0.27 & 4.28 & 10.10 & 11.03 & 2.58 & $6 \%$ & 4.98 \\
\hline $\mathrm{C}-7-\mathrm{F}$ & 4.46 & 0.26 & 4.10 & 10.08 & 14.06 & 3.43 & $8 \%$ & 5.08 \\
\hline $\mathrm{C}-8-\mathrm{F}$ & 10.29 & 0.26 & 7.99 & 10.17 & 88.55 & 11.09 & $22 \%$ & 5.01 \\
\hline $\mathrm{C}-9-\mathrm{F}$ & 20.06 & 0.26 & 13.44 & 10.53 & 271.87 & 20.23 & $33 \%$ & 5.26 \\
\hline
\end{tabular}


Table 6.8: Neptunium-NOM Sandy Sediment Centrifuged Data

\begin{tabular}{|c|c|c|c|c|c|c|c|c|}
\hline Sample & {$[\mathrm{Np}]_{\mathrm{o}}$} & $\begin{array}{c}\text { Mass } \\
\text { Sediment }\end{array}$ & {$[\mathrm{Np}]_{\text {aqu }}$} & Liq Mass & {$[\mathrm{Np}]_{\text {sediment }}$} & $\mathrm{K}_{\mathrm{d}}$ & $\%$ Sorbed & $\mathrm{pH}$ \\
\hline Units & $\mathrm{ppb}$ & $\mathrm{g}$ & $\mathrm{ppb}$ & & $\mathrm{ppb}$ & $\mathrm{L} \mathrm{kg}^{-1}$ & & \\
\hline S-1-C & 0.09 & 0.26 & 0.07 & 9.73 & 0.56 & 7.52 & $17 \%$ & 5.69 \\
\hline S-2-C & 0.45 & 0.27 & 0.41 & 10.09 & 1.53 & 3.75 & $9 \%$ & 5.70 \\
\hline S-3-C & 0.91 & 0.26 & 0.73 & 9.94 & 6.86 & 9.37 & $20 \%$ & 5.74 \\
\hline S-4-C & 0.93 & 0.26 & 0.89 & 9.87 & 1.57 & 1.76 & $5 \%$ & 5.55 \\
\hline S-5-C & 1.84 & 0.26 & 1.47 & 9.94 & 14.25 & 9.66 & $20 \%$ & 5.68 \\
\hline S-6-C & 4.48 & 0.26 & 4.17 & 10.07 & 12.12 & 2.91 & $7 \%$ & 5.66 \\
\hline S-7-C & 4.55 & 0.26 & 4.47 & 9.99 & 3.18 & 0.71 & $2 \%$ & 5.43 \\
\hline S-8-C & 10.18 & 0.26 & 8.36 & 10.27 & 72.03 & 8.62 & $18 \%$ & 5.68 \\
\hline S-9-C & 20.21 & 0.25 & 13.06 & 10.40 & 292.03 & 22.36 & $35 \%$ & 5.91 \\
\hline
\end{tabular}

Table 6.9: Neptunium-NOM Sandy Sediment Filtrate Data

\begin{tabular}{|c|c|c|c|c|c|c|c|c|}
\hline Sample & {$[\mathrm{Np}]_{\mathrm{o}}$} & $\begin{array}{c}\text { Mass } \\
\text { Sediment }\end{array}$ & {$[\mathrm{Np}]_{\mathrm{aqu}}$} & Liq Mass & {$[\mathrm{Np}]_{\text {sediment }}$} & $\mathrm{K}_{\mathrm{d}}$ & $\%$ Sorbed & $\mathrm{pH}$ \\
\hline Units & $\mathrm{ppb}$ & $\mathrm{g}$ & $\mathrm{ppb}$ & & $\mathrm{ppb}$ & $\mathrm{L} \mathrm{kg}^{-1}$ & & \\
\hline \hline $\mathrm{S}-1-\mathrm{F}$ & 0.09 & 0.26 & 0.07 & 9.73 & 0.68 & 9.45 & $20 \%$ & 5.69 \\
\hline S-2-F & 0.45 & 0.27 & 0.40 & 10.09 & 1.92 & 4.85 & $11 \%$ & 5.70 \\
\hline S-3-F & 0.91 & 0.26 & 0.70 & 9.94 & 8.10 & 11.58 & $23 \%$ & 5.74 \\
\hline S-4-F & 0.93 & 0.26 & 0.85 & 9.87 & 3.12 & 3.67 & $9 \%$ & 5.55 \\
\hline S-5-F & 1.84 & 0.26 & 1.91 & 9.94 & -2.84 & -1.48 & $-4 \%$ & 5.68 \\
\hline S-6-F & 4.48 & 0.26 & 4.02 & 10.07 & 17.82 & 4.43 & $10 \%$ & 5.66 \\
\hline S-7-F & 4.55 & 0.26 & 4.28 & 9.99 & 10.30 & 2.41 & $6 \%$ & 5.43 \\
\hline S-8-F & 10.18 & 0.26 & 8.03 & 10.27 & 84.92 & 10.57 & $21 \%$ & 5.68 \\
\hline S-9-F & 20.21 & 0.25 & 12.67 & 10.40 & 308.06 & 24.32 & $37 \%$ & 5.91 \\
\hline
\end{tabular}


Table 6.10: Neptunium-Varying NOM Clayey Sediment Centrifuged Data

\begin{tabular}{|c|c|c|c|c|c|c|c|c|c|}
\hline Sample & {$[\mathrm{Np}]_{\mathrm{o}}$} & {$[\mathrm{NOM}]_{\mathrm{o}}$} & $\begin{array}{c}\text { Mass } \\
\text { Sediment }\end{array}$ & {$[\mathrm{Np}]_{\text {aqu }}$} & Liq Mass & {$[\mathrm{Np}]_{\text {sediment }}$} & $\mathrm{K}_{\mathrm{d}}$ & $\begin{array}{c}\% \\
\text { Sorption }\end{array}$ & $\mathrm{pH}$ \\
\hline Units & $\mathrm{ppb}$ & $\mathrm{mg} \mathrm{L}^{-1}$ & $\mathrm{~g}$ & $\mathrm{ppb}$ & $\mathrm{g}$ & $\mathrm{ppb}$ & $\mathrm{L} \mathrm{kg}^{-1}$ & & \\
\hline C-1-C & 10.90 & 0.00 & 0.23 & 6.58 & 9.52 & 182.47 & 27.74 & $40 \%$ & 5.55 \\
\hline C-2-C & 11.35 & 4.92 & 0.24 & 7.09 & 9.48 & 167.20 & 23.58 & $38 \%$ & 5.45 \\
\hline C-3-C & 11.36 & 4.99 & 0.26 & 6.59 & 9.57 & 177.20 & 26.90 & $42 \%$ & 5.60 \\
\hline C-4-C & 10.60 & 9.62 & 0.25 & 6.12 & 10.10 & 184.05 & 30.06 & $42 \%$ & 5.49 \\
\hline C-5-C & 11.08 & 9.73 & 0.24 & 6.24 & 9.65 & 192.29 & 30.82 & $44 \%$ & 5.44 \\
\hline C-6-C & 11.16 & 14.97 & 0.24 & 7.01 & 9.68 & 165.90 & 23.67 & $37 \%$ & 5.49 \\
\hline C-7-C & 11.25 & 15.20 & 0.27 & 6.95 & 9.56 & 152.02 & 21.88 & $38 \%$ & 5.66 \\
\hline C-8-C & 11.24 & 20.44 & 0.25 & 6.94 & 9.54 & 166.01 & 23.93 & $38 \%$ & 5.69 \\
\hline
\end{tabular}

Table 6.11: Neptunium-Varying NOM Clayey Sediment Filtrate Data

\begin{tabular}{|c|c|c|c|c|c|c|c|c|c|}
\hline Sample & {$[\mathrm{Np}]_{\mathrm{o}}$} & {$[\mathrm{NOM}]_{\mathrm{o}}$} & $\begin{array}{c}\text { Mass } \\
\text { Sediment }\end{array}$ & {$[\mathrm{Np}]_{\text {aqu }}$} & Liq Mass & {$[\mathrm{Np}]_{\text {sediment }}$} & $\mathrm{K}_{\mathrm{d}}$ & $\begin{array}{c}\% \\
\text { Sorption }\end{array}$ & $\mathrm{pH}$ \\
\hline Units & $\mathrm{ppb}$ & $\mathrm{mg} \mathrm{L}$ & $\mathrm{g}$ & $\mathrm{ppb}$ & $\mathrm{g}$ & $\mathrm{ppb}$ & $\mathrm{L} \mathrm{kg}^{-1}$ & & \\
\hline C-1-F & 10.90 & 0.00 & 0.23 & 6.38 & 9.52 & 190.90 & 29.93 & $41 \%$ & 5.55 \\
\hline C-2-F & 11.35 & 4.92 & 0.24 & 6.88 & 9.48 & 175.41 & 25.49 & $39 \%$ & 5.45 \\
\hline C-3-F & 11.36 & 4.99 & 0.26 & 6.30 & 9.57 & 187.97 & 29.85 & $45 \%$ & 5.60 \\
\hline C-4-F & 10.60 & 9.62 & 0.25 & 5.81 & 10.10 & 196.73 & 33.84 & $45 \%$ & 5.49 \\
\hline C-5-F & 11.08 & 9.73 & 0.24 & 5.95 & 9.65 & 203.72 & 34.23 & $46 \%$ & 5.44 \\
\hline C-6-F & 11.16 & 14.97 & 0.24 & 6.84 & 9.68 & 172.65 & 25.24 & $39 \%$ & 5.49 \\
\hline C-7-F & 11.25 & 15.20 & 0.27 & 6.79 & 9.56 & 157.60 & 23.21 & $40 \%$ & 5.66 \\
\hline C-8-F & 11.24 & 20.44 & 0.25 & 6.60 & 9.54 & 179.05 & 27.13 & $41 \%$ & 5.69 \\
\hline
\end{tabular}

Table 6.12: Neptunium-Varying NOM Sandy Sediment Centrifuged Data

\begin{tabular}{|c|c|c|c|c|c|c|c|c|c|}
\hline Sample & {$[\mathrm{Np}]_{\mathrm{o}}$} & {$[\mathrm{NOM}]_{\mathrm{o}}$} & $\begin{array}{c}\text { Mass } \\
\text { Sediment }\end{array}$ & {$[\mathrm{Np}]_{\text {aqu }}$} & Liq Mass & {$[\mathrm{Np}]_{\text {sediment }}$} & $\mathrm{K}_{\mathrm{d}}$ & $\begin{array}{c}\% \\
\text { Sorption }\end{array}$ & $\mathrm{pH}$ \\
\hline Units & $\mathrm{ppb}$ & $\mathrm{mg} \mathrm{L}^{-1}$ & $\mathrm{~g}$ & $\mathrm{ppb}$ & $\mathrm{g}$ & $\mathrm{ppb}$ & $\mathrm{L} \mathrm{kg}^{-1}$ & & \\
\hline \hline S-1-C & 11.12 & 5.03 & 0.26 & 8.50 & 9.70 & 98.80 & 11.62 & $24 \%$ & 5.56 \\
\hline S-2-C & 11.10 & 4.86 & 0.24 & 8.36 & 9.54 & 106.67 & 12.76 & $25 \%$ & 5.53 \\
\hline S-3-C & 10.54 & 9.60 & 0.25 & 8.38 & 10.10 & 88.28 & 10.54 & $21 \%$ & 5.49 \\
\hline S-4-C & 10.81 & 9.73 & 0.26 & 8.84 & 9.86 & 74.96 & 8.48 & $18 \%$ & 5.41 \\
\hline S-5-C & 10.74 & 14.56 & 0.25 & 8.47 & 9.91 & 90.31 & 10.66 & $21 \%$ & 5.48 \\
\hline S-6-C & 10.79 & 14.36 & 0.25 & 8.33 & 9.97 & 98.50 & 11.83 & $23 \%$ & 5.49 \\
\hline S-7-C & 11.10 & 19.86 & 0.24 & 8.02 & 9.63 & 122.79 & 15.31 & $28 \%$ & 5.61 \\
\hline S-8-C & 11.15 & 0.00 & 0.25 & 9.56 & 9.58 & 60.45 & 6.32 & $14 \%$ & 5.49 \\
\hline
\end{tabular}


Table 6.13: Neptunium-Varying NOM Sandy Sediment Filtrate Data

\begin{tabular}{|c|c|c|c|c|c|c|c|c|c|}
\hline Sample & {$[\mathrm{Np}]_{\mathrm{o}}$} & {$[\mathrm{NOM}]_{\mathrm{o}}$} & $\begin{array}{c}\text { Mass } \\
\text { Sediment }\end{array}$ & {$[\mathrm{Np}]_{\text {aqu }}$} & Liq Mass & {$[\mathrm{Np}]_{\text {sediment }}$} & $\mathrm{K}_{\mathrm{d}}$ & $\begin{array}{c}\% \\
\text { Sorption }\end{array}$ & $\mathrm{pH}$ \\
\hline Units & $\mathrm{ppb}$ & $\mathrm{mg} \mathrm{L}^{-1}$ & $\mathrm{~g}$ & $\mathrm{ppb}$ & $\mathrm{g}$ & $\mathrm{ppb}$ & $\mathrm{L} \mathrm{kg}^{-1}$ & & \\
\hline S-1-F & 11.12 & 5.03 & 0.26 & 8.03 & 9.70 & 116.52 & 14.51 & $28 \%$ & 5.56 \\
\hline S-2-F & 11.10 & 4.86 & 0.24 & 8.07 & 9.54 & 117.86 & 14.60 & $27 \%$ & 5.53 \\
\hline S-3-F & 10.54 & 9.60 & 0.25 & 8.31 & 10.10 & 91.06 & 10.96 & $21 \%$ & 5.49 \\
\hline S-4-F & 10.81 & 9.73 & 0.26 & 8.68 & 9.86 & 80.97 & 9.32 & $20 \%$ & 5.41 \\
\hline S-5-F & 10.74 & 14.56 & 0.25 & 8.30 & 9.91 & 97.42 & 11.74 & $23 \%$ & 5.48 \\
\hline S-6-F & 10.79 & 14.36 & 0.25 & 8.11 & 9.97 & 107.35 & 13.24 & $25 \%$ & 5.49 \\
\hline S-7-F & 11.10 & 19.86 & 0.24 & 7.79 & 9.63 & 131.77 & 16.91 & $30 \%$ & 5.61 \\
\hline S-8-F & 11.15 & 0.00 & 0.25 & 9.23 & 9.58 & 72.84 & 7.89 & $17 \%$ & 5.49 \\
\hline
\end{tabular}




\subsection{Reductant Addition Data}

Table 6.14: Reductant Addition Clayey Sediment Centrifuged Data

\begin{tabular}{|c|c|c|c|c|c|c|c|c|}
\hline Sample & {$[\mathrm{Np}]_{\mathrm{o}}$} & $\begin{array}{c}\text { Mass } \\
\text { Sediment }\end{array}$ & {$[\mathrm{Np}]_{\mathrm{aqu}}$} & Liq Mass & $\begin{array}{c}{[\mathrm{Np}]} \\
\text { sediment }\end{array}$ & $\mathrm{K}_{\mathrm{d}}$ & $\begin{array}{c}\% \\
\text { Sorption }\end{array}$ & $\mathrm{pH}$ \\
\hline Units & $\mathrm{ppb}$ & $\mathrm{g}$ & $\mathrm{ppb}$ & & $\mathrm{ppb}$ & $\mathrm{L} \mathrm{kg}^{-1}$ & & \\
\hline \hline Ascorbic Acid & 10.56 & 0.26 & 6.78 & 9.83 & 142.87 & 21.06 & $36 \%$ & 5.30 \\
\hline Zero Valent Iron & 11.23 & 0.24 & 7.02 & 9.66 & 166.13 & 23.65 & $37 \%$ & 5.29 \\
\hline Dithionide & 11.39 & 0.24 & 7.22 & 9.59 & 165.85 & 22.96 & $37 \%$ & 5.39 \\
\hline Hydrogen Peroxide & 10.84 & 0.26 & 8.13 & 9.71 & 101.39 & 12.47 & $25 \%$ & 5.28 \\
\hline
\end{tabular}

Table 6.15: Reductant Addition Clayey Sediment Filtrate Data

\begin{tabular}{|c|c|c|c|c|c|c|c|c|}
\hline Sample & {$[\mathrm{Np}]_{\mathrm{o}}$} & $\begin{array}{c}\text { Mass } \\
\text { Sediment }\end{array}$ & {$[\mathrm{Np}]_{\mathrm{aqu}}$} & Liq Mass & $\begin{array}{c}{[\mathrm{Np}]} \\
\text { sediment }\end{array}$ & $\mathrm{K}_{\mathrm{d}}$ & $\begin{array}{c}\% \\
\text { Sorption }\end{array}$ & $\mathrm{pH}$ \\
\hline Units & $\mathrm{ppb}$ & $\mathrm{g}$ & $\mathrm{ppb}$ & & $\mathrm{ppb}$ & $\mathrm{L} \mathrm{kg}^{-1}$ & & \\
\hline Ascorbic Acid & 11.06 & 0.25 & 8.36 & 9.68 & 106.63 & 12.76 & $24 \%$ & 5.30 \\
\hline Zero Valent Iron & 10.81 & 0.25 & 8.40 & 10.28 & 100.76 & 11.99 & $22 \%$ & 5.29 \\
\hline Dithionide & 11.04 & 0.24 & 8.61 & 9.68 & 95.98 & 11.14 & $22 \%$ & 5.39 \\
\hline Hydrogen Peroxide & 10.99 & 0.25 & 8.87 & 9.72 & 81.86 & 9.23 & $19 \%$ & 5.28 \\
\hline
\end{tabular}


Table 6.16: Reductant Addition Sandy Sediment Centrifuged Data

\begin{tabular}{|c|c|c|c|c|c|c|c|c|}
\hline Sample & {$[\mathrm{Np}]_{\mathrm{o}}$} & $\begin{array}{c}\text { Mass } \\
\text { Sediment }\end{array}$ & {$[\mathrm{Np}]_{\mathrm{aqu}}$} & Liq Mass & $\begin{array}{c}{[\mathrm{Np}]} \\
\text { sediment }\end{array}$ & $\mathrm{K}_{\mathrm{d}}$ & $\begin{array}{c}\% \\
\text { Sorption } \\
\end{array}$ & $\mathrm{pH}$ \\
\hline Units & $\mathrm{ppb}$ & g & $\mathrm{ppb}$ & & $\mathrm{ppb}$ & $\mathrm{L} \mathrm{kg}^{-1}$ & & \\
\hline Ascorbic Acid & 10.56 & 0.26 & 6.41 & 9.83 & 157.14 & 24.53 & $39 \%$ & 5.84 \\
\hline Zero Valent Iron & 11.23 & 0.24 & 6.80 & 9.66 & 175.05 & 25.75 & $39 \%$ & 5.70 \\
\hline Dithionide & 11.39 & 0.24 & 6.94 & 9.59 & 176.97 & 25.49 & $39 \%$ & 5.73 \\
\hline Hydrogen Peroxide & 10.84 & 0.26 & 8.01 & 9.71 & 105.90 & 13.22 & $26 \%$ & 5.63 \\
\hline
\end{tabular}

Table 6.17: Reductant Addition Sandy Sediment Filtrate Data

\begin{tabular}{|c|c|c|c|c|c|c|c|c|}
\hline Sample & {$[\mathrm{Np}]_{\mathrm{o}}$} & $\begin{array}{c}\text { Mass } \\
\text { Sediment }\end{array}$ & {$[\mathrm{Np}]_{\mathrm{aqu}}$} & Liq Mass & $\begin{array}{c}{[\mathrm{Np}]} \\
\text { sediment }\end{array}$ & $\mathrm{K}_{\mathrm{d}}$ & $\begin{array}{c}\% \% \\
\text { Sorption }\end{array}$ & $\mathrm{pH}$ \\
\hline Units & $\mathrm{ppb}$ & $\mathrm{g}$ & $\mathrm{ppb}$ & & $\mathrm{ppb}$ & $\mathrm{L} \mathrm{kg}^{-1}$ & & \\
\hline Ascorbic Acid & 11.06 & 0.25 & 8.33 & 9.68 & 107.50 & 12.90 & $25 \%$ & 5.84 \\
\hline Zero Valent Iron & 10.81 & 0.25 & 8.31 & 10.28 & 104.50 & 12.57 & $23 \%$ & 5.70 \\
\hline Dithionide & 11.04 & 0.24 & 8.68 & 9.68 & 93.46 & 10.77 & $21 \%$ & 5.73 \\
\hline Hydrogen Peroxide & 10.99 & 0.25 & 8.85 & 9.72 & 82.44 & 9.31 & $19 \%$ & 5.63 \\
\hline
\end{tabular}


6.4 $\underline{\text { Anaerobic Data }}$

Table 6.18: Anaerobic Glovebox Clayey Sediment Centrifuged Data

\begin{tabular}{|c|c|c|c|c|c|c|c|c|}
\hline Sample & {$[\mathrm{Np}]_{\mathrm{o}}$} & $\begin{array}{c}\text { Mass } \\
\text { Sediment }\end{array}$ & {$[\mathrm{Np}]_{\mathrm{aqu}}$} & Liq Mass & {$[\mathrm{Np}]_{\text {sediment }}$} & $\mathrm{K}_{\mathrm{d}}$ & $\%$ Sorbed & $\mathrm{pH}$ \\
\hline Units & $\mathrm{ppb}$ & $\mathrm{g}$ & $\mathrm{ppb}$ & & $\mathrm{ppb}$ & $\mathrm{L} \mathrm{kg}^{-1}$ & & \\
\hline C-1-C & 0.25 & 0.26 & 0.21 & 9.60 & 1.47 & 6.99 & $16 \%$ & 5.44 \\
\hline C-2-C & 0.59 & 0.26 & 0.44 & 9.36 & 5.47 & 12.57 & $26 \%$ & 5.51 \\
\hline C-3-C & 1.14 & 0.27 & 0.85 & 9.59 & 10.56 & 12.48 & $26 \%$ & 5.42 \\
\hline C-4-C & 1.14 & 0.26 & 0.85 & 9.58 & 10.47 & 12.27 & $25 \%$ & 5.48 \\
\hline C-5-C & 2.28 & 0.26 & 1.67 & 9.61 & 22.65 & 13.55 & $27 \%$ & 5.58 \\
\hline C-6-C & 5.65 & 0.26 & 4.15 & 9.67 & 55.04 & 13.26 & $26 \%$ & 5.59 \\
\hline C-7-C & 5.73 & 0.25 & 4.28 & 9.50 & 55.10 & 12.88 & $25 \%$ & 5.56 \\
\hline C-8-C & 10.12 & 0.25 & 7.64 & 9.99 & 98.45 & 12.89 & $25 \%$ & 5.53 \\
\hline C-9-C & 10.41 & 0.26 & 7.78 & 9.74 & 97.11 & 12.48 & $25 \%$ & 5.50 \\
\hline C-10-C & 21.23 & 0.26 & 13.75 & 9.57 & 280.66 & 20.42 & $35 \%$ & 5.46 \\
\hline
\end{tabular}

Table 6.19: Anaerobic Glovebox Clayey Sediment Filtrate Data

\begin{tabular}{|c|c|c|c|c|c|c|c|c|}
\hline Sample & {$[\mathrm{Np}]_{\mathrm{o}}$} & $\begin{array}{c}\text { Mass } \\
\text { Sediment }\end{array}$ & {$[\mathrm{Np}]_{\mathrm{aqu}}$} & Liq Mass & {$[\mathrm{Np}]_{\text {sediment }}$} & $\mathrm{K}_{\mathrm{d}}$ & $\%$ Sorbed & $\mathrm{pH}$ \\
\hline Units & $\mathrm{ppb}$ & $\mathrm{g}$ & $\mathrm{ppb}$ & & $\mathrm{ppb}$ & $\mathrm{L} \mathrm{kg}^{-1}$ & & \\
\hline \hline $\mathrm{C}-1-\mathrm{F}$ & 0.25 & 0.26 & 0.21 & 9.60 & 1.36 & 6.38 & $15 \%$ & 5.44 \\
\hline $\mathrm{C}-2-\mathrm{F}$ & 0.59 & 0.26 & 0.43 & 9.36 & 5.71 & 13.32 & $27 \%$ & 5.51 \\
\hline $\mathrm{C}-3-\mathrm{F}$ & 1.14 & 0.27 & 0.84 & 9.59 & 10.65 & 12.61 & $26 \%$ & 5.42 \\
\hline $\mathrm{C}-4-\mathrm{F}$ & 1.14 & 0.26 & 0.79 & 9.58 & 12.77 & 16.15 & $31 \%$ & 5.48 \\
\hline $\mathrm{C}-5-\mathrm{F}$ & 2.28 & 0.26 & 1.67 & 9.61 & 22.89 & 13.74 & $27 \%$ & 5.58 \\
\hline $\mathrm{C}-6-\mathrm{F}$ & 5.65 & 0.26 & 4.14 & 9.67 & 55.64 & 13.45 & $27 \%$ & 5.59 \\
\hline $\mathrm{C}-7-\mathrm{F}$ & 5.73 & 0.25 & 4.23 & 9.50 & 56.97 & 13.47 & $26 \%$ & 5.56 \\
\hline $\mathrm{C}-8-\mathrm{F}$ & 10.12 & 0.25 & 7.67 & 9.99 & 97.05 & 12.65 & $24 \%$ & 5.53 \\
\hline $\mathrm{C}-9-\mathrm{F}$ & 10.41 & 0.26 & 7.90 & 9.74 & 92.75 & 11.75 & $24 \%$ & 5.50 \\
\hline C-10-F & 21.23 & 0.26 & 13.75 & 9.57 & 280.70 & 20.42 & $35 \%$ & 5.46 \\
\hline
\end{tabular}


Table 6.20: Anaerobic Glovebox Sandy Sediment Centrifuged Data

\begin{tabular}{|c|c|c|c|c|c|c|c|c|}
\hline Sample & {$[\mathrm{Np}]_{\mathrm{o}}$} & $\begin{array}{c}\text { Mass } \\
\text { Sediment }\end{array}$ & {$[\mathrm{Np}]_{\mathrm{aqu}}$} & Liq Mass & {$[\mathrm{Np}]_{\text {sediment }}$} & $\mathrm{K}_{\mathrm{d}}$ & $\%$ Sorbed & $\mathrm{pH}$ \\
\hline Units & $\mathrm{ppb}$ & $\mathrm{g}$ & $\mathrm{ppb}$ & & $\mathrm{ppb}$ & $\mathrm{L} \mathrm{kg}^{-1}$ & & \\
\hline \hline S-1-C & 0.12 & 0.26 & 0.12 & 9.55 & -0.06 & -0.51 & $-1 \%$ & 5.46 \\
\hline S-2-C & 0.58 & 0.26 & 0.51 & 9.47 & 2.72 & 5.37 & $13 \%$ & 5.52 \\
\hline S-3-C & 1.15 & 0.26 & 0.96 & 9.53 & 6.88 & 7.17 & $16 \%$ & 5.56 \\
\hline S-4-C & 1.13 & 0.26 & 0.99 & 9.54 & 5.33 & 5.39 & $13 \%$ & 5.40 \\
\hline S-5-C & 2.23 & 0.25 & 1.88 & 9.82 & 13.46 & 7.16 & $16 \%$ & 5.60 \\
\hline S-6-C & 5.62 & 0.26 & 4.81 & 9.72 & 30.20 & 6.27 & $14 \%$ & 5.47 \\
\hline S-7-C & 5.54 & 0.25 & 4.88 & 9.84 & 25.88 & 5.30 & $12 \%$ & 5.51 \\
\hline S-8-C & 10.68 & 0.26 & 9.02 & 9.49 & 61.38 & 6.81 & $16 \%$ & 5.60 \\
\hline S-9-C & 10.53 & 0.26 & 9.44 & 9.65 & 41.24 & 4.37 & $10 \%$ & 5.44 \\
\hline S-10-C & 21.90 & 0.25 & 19.77 & 9.24 & 77.88 & 3.94 & $10 \%$ & 5.48 \\
\hline
\end{tabular}


Table 6.21: Anaerobic Glovebox Sandy Sediment Filtrate Data

\begin{tabular}{|c|c|c|c|c|c|c|c|c|}
\hline Sample & {$[\mathrm{Np}]_{\mathrm{o}}$} & $\begin{array}{c}\text { Mass } \\
\text { Sediment }\end{array}$ & {$[\mathrm{Np}]_{\mathrm{aqu}}$} & Liq Mass & {$[\mathrm{Np}]_{\text {sediment }}$} & $K_{d}$ & $\%$ Sorbed & $\mathrm{pH}$ \\
\hline Units & $\mathrm{ppb}$ & g & $\mathrm{ppb}$ & & $\mathrm{ppb}$ & $\mathrm{L} \mathrm{kg}^{-1}$ & & \\
\hline S-1-F & 0.12 & 0.26 & 0.10 & 9.55 & 0.63 & 6.13 & $14 \%$ & 5.46 \\
\hline S-2-F & 0.58 & 0.26 & 0.48 & 9.47 & 3.79 & 7.93 & $18 \%$ & 5.52 \\
\hline S-3-F & 1.15 & 0.26 & 0.95 & 9.53 & 7.36 & 7.77 & $17 \%$ & 5.56 \\
\hline S-4-F & 1.13 & 0.26 & 0.94 & 9.54 & 7.06 & 7.49 & $17 \%$ & 5.40 \\
\hline S-5-F & 2.23 & 0.25 & 1.88 & 9.82 & 13.57 & 7.23 & $16 \%$ & 5.60 \\
\hline S-6-F & 5.62 & 0.26 & 4.80 & 9.72 & 30.86 & 6.43 & $15 \%$ & 5.47 \\
\hline S-7-F & 5.54 & 0.25 & 4.76 & 9.84 & 30.62 & 6.44 & $14 \%$ & 5.51 \\
\hline S-8-F & 10.68 & 0.26 & 8.97 & 9.49 & 62.92 & 7.01 & $16 \%$ & 5.60 \\
\hline S-9-F & 10.53 & 0.26 & 9.23 & 9.65 & 48.93 & 5.30 & $12 \%$ & 5.44 \\
\hline S-10-F & 21.90 & 0.25 & 19.71 & 9.24 & 80.06 & 4.06 & $10 \%$ & 5.48 \\
\hline
\end{tabular}




\section{DISTRIBUTION:}

Savannah River Site
B. T. Butcher
773-43A, Rm. 211
D. A. Crowley
773-43A. Rm. 214
M. E. Denham
773-42A, Rm. 218
W. T. Goldston
705-3C, Rm. 105
J. C. Griffin
773A, Rm. A-231
D. I. Kaplan (3 copies)
773-43A, Rm. 215
S. L. Marra
773A, Rm. A-230
K. A. Roberts
773-43A, Rm. 225
RPA File (2 copies)
773-43A, Rm. 213

Clemson University, Environmental Engineering and Earth Sciences, 372 Computer Court, L.G. Rich Environmental Laboratory, Anderson, SC 29625

T. J. Miller (3 Copies)

B. A. Powell 